\title{
Exploring the Feasibility of Establishing a Core Set of Sexual, Reproductive, Maternal, Newborn, Child, and Adolescent Health Indicators in Humanitarian Settings: Results From a Multi-methods Assessment in Jordan
}

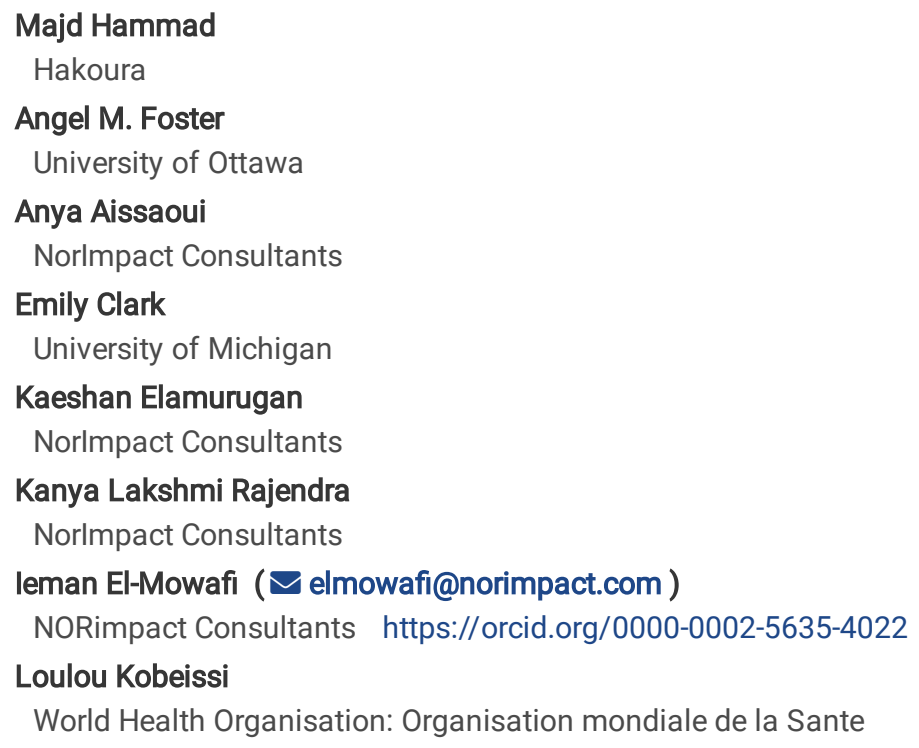

\section{Research Article}

Keywords: Jordan, Monitoring and Evaluating, Sexual and Reproductive Health, Maternal, Child and Adolescent Health, Humanitarian data reporting, Health Information Systems

Posted Date: January 25th, 2022

DOI: https://doi.org/10.21203/rs.3.rs-1200393/v1

License: (c) (i) This work is licensed under a Creative Commons Attribution 4.0 International License. Read Full License 


\section{Abstract}

Background: Reliable and rigorously collected sexual, reproductive, maternal, newborn, child, and adolescent health (SRMNCAH) data in humanitarian settings is often sparse and variable in quality across different humanitarian settings. To address this gap in data quality, the World Health Organization (WHO) developed a core set of indicators for monitoring and evaluating SRMNCAH services and outcomes in humanitarian settings, and assessed their feasibility in the field in Jordan, in addition to three other countries; with the goal of aggregating information from global consultations and field-level assessments to reach consensus on a set of core SRMNCAH indicators for services and outcome evaluation in humanitarian settings among WHO global partners.

Methods: The feasibility assessment in Jordan focused on the following constructs: relevance/usefulness, feasibility of measurement, systems and resources, and ethical issues. The multi-methods assessment included five components; a desk review, key informant interviews, focus group discussions, facility assessments, and observational sessions.

Results: Findings suggest that there is widespread support among regional, national, as well as global stakeholders for developing a core list of SRMNCAH indicators for monitoring and evaluation of services and outcomes in humanitarian settings in Jordan. There are numerous resources and data collection systems that could be leveraged, built upon, and improved to ensure the feasibility of collecting this proposed set of indicators. However, the data collection load requested from donors, the national government, international and UN agencies, coordination/cluster systems must be better harmonized, standardized, and less burdensome.

Conclusions: Despite stakeholder support in developing a core set of indicators, this would only be useful if it has the buy-in from the international community. Greater harmonization and coordination, alongside increased resource allocation, would improve data collection efforts and allow stakeholders to meet indicators' reporting requirements.

\section{Plain English Summary}

In humanitarian settings, data collection is often unreliable and not standardized - especially with regards to sexual, reproductive, maternal, newborn, child, and adolescent health (SRMNCAH). In order to address this gap in data quality, the World Health Organization proposed a list of core indicators to four countries, including Jordan. The goal was to use the findings from the Jordanian context to contribute to the determination of a core set of indicators, and accumulate a list of necessary policy, funding, infrastructure, capacity and training that will be required.

This study had two components: a feasibility assessment and a multi-methods assessment. The feasibility assessment in Jordan focused on the relevance of the proposed indicators, the feasibility of measurement, the resources in place, and ethical issues. The multi-methods assessment included a desk review, interviews with key informants and focus groups, and facility assessments (including observational sessions).

The findings showed that partners in Jordan supported developing a standard set of SRMCAH indicators that can be used among all humanitarian partners in the country. There are a number of systems in place that could be used or strengthened to improve data collection. However, the findings also showed that there must be better collaboration and coordination between the different partners in Jordan, as well as increased resources, to alleviate burden on front-line staff, starting with standardizing and strengthening Jordan's health information system (HIS).

In conclusion, though there is a desire to harmonize indicators, more input and resources are needed from the international community to aid in the standardization of data collection in order to meet local reporting requirements and ease burden on local staff.

\section{Background}

\section{Syrian crisis in Jordan}

As the Syrian crisis continues, Jordan hosts more than 650,000 registered Syrian refugees in both urban and camp settings (1), and another estimated 1.2 million unregistered refugees in urban and rural areas across the country (2). The majority of Syrian refugees in Jordan (79\%) live outside refugee camps (1) in urban and rural areas throughout the country, and Syrians who reside in these communities have less access to, or have more difficulty navigating, local health services (3). As of 2021, approximately fifty percent of refugees in Jordan are women and girls. Of this population, 160,000 are women of reproductive age (2), an estimated 16,000 of whom are pregnant at any given time (4). More than half of these pregnant women are under the age of 25 (5). This has caused considerable strain on Jordan's already weak existing infrastructure and consequently imposed many implications on sexual, reproductive, maternal, newborn, child, and adolescent health (SRMNCAH) services, access, and outcomes $(3,6-8)$.

\section{SRMNCAH data collection and indicator reporting}

Page $2 / 32$ 
Humanitarian emergencies are frequently characterized by the collapse and fragmentation of basic health services $(9,10)$. In addition to the strain caused by humanitarian emergencies on host countries' health systems and services, the large influx of refugees into Jordan has placed an unsustainable strain on the economy $(11,12)$, infrastructure, and security systems $(13)$; consequently, organizations are unable to meet the simultaneous demands of both refugees and its residents (10). For better decision-making, coordination and response in crisis settings such as Jordan, multi-lateral and bilateral humanitarian agencies and their implementing partners need access to appropriate information (14-16). Over the last few decades, researchers have extensively reported that humanitarian emergencies could generally lead to either a shortage or an overload of information - and both situations impair the provision of effective humanitarian assistance $(16,17)$.

Timely and rigorous collection, aggregation, and use of SRMNCAH data for services and outcomes evaluation in humanitarian settings is an important component of accountability and transparency within the aid community, and most importantly, accountability for the populations that the programs and developments are catered to (18). Collecting complete, reliable, and quality data is also key to increase aid efficiently and effectively for populations affected by emergency and humanitarian crises $(17,19)$. Transparency, accountability and measurement of the impact of humanitarian interventions are not only important for humanitarian organisations but are often requirements set by donors (16, 20). Rigorous data collection and analysis would contribute to measurable assessments of the objectives, goals, and purpose of humanitarian initiatives in terms of process, impact, and intended outcomes $(21,22)$.

\section{SRMNCAH data collection and indicator reporting in Jordan}

In the Jordanian context, multiple concerted efforts have been made to address the gaps in availability of SRMNCAH data. The most recent of such efforts is led by the Higher Population Council National Strategy for Reproductive Health and Family Planning (NSRHFP) by creating guidelines to support and engage key stakeholders in the coordination of all sexual and reproductive health (SRH) efforts in the country, including the data needed to meet the agreed upon national goals and global standards of care (23). However, with a three-tiered health care system, limited budgets, and varying policies and regulations, the development of national priorities and guidelines for improving SRMNCAH indicators' reporting for its population - and for refugee populations more specifically - has proven to be challenging (24).

\section{Aims and objectives}

In light of the above, WHO, in close coordination with local, regional, and global partners, agreed to test the feasibility of a candidate set of SRMNCAH indicators for humanitarian settings at the field level. This was done in four countries experiencing different types of humanitarian crises, including Jordan, to determine the feasibility, relevance, and acceptability of these indicators. In the article, we discuss the results of this assessment in Jordan. The assessment took place in both camp and urban settings in the capital city of Amman as well as in Irbid and Mafraq (Al-Za'atari), and Karak and Aqaba in the North and South regions of Jordan, respectively.

By assessing feasibility, we aimed to explore the potential impact of the intended data collection and analysis, whether or not national and nongovernmental monitoring and evaluation systems have the needed resources to collect SRMNCAH indicators, and the ability of the system to adhere to ethical practice and safeguard clients' confidentiality and privacy. The results of Jordan's country level assessment will be eventually aggregated with the results from other field-level assessments in order to reach a global consensus on a minimum set of core SRMNCAH indicators for services and outcomes evaluation in humanitarian settings among donor agencies, UN agencies, and international NGOs working in humanitarian settings.

\section{Methods \\ Study Design}

This multi-methods assessment consisted of five main components: 1) a desk review of published articles and reports as well as internal documents (in English and Arabic); 2) key informant interviews with representatives from government entities, international non-governmental organizations, and community-based organizations; 3 ) facility assessments at primary, secondary, and tertiary facilities that provide services to refugees in Jordan; 4) observation sessions focused on the logistical, ethical, and privacy practices associated with data collection and storage at select facilities; and 5) focus group discussions (FGD) with frontline workers at primary, secondary, and tertiary health centers (see figure 1).

The assessment centered on seeking and understanding different stakeholders' perceptions and attitudes towards: SRMNCAH issues in Jordan, SRMNCAH service provision in Jordan for refugee populations, current reporting practices on SRMNCAH indicators, and the feasibility of reporting on the candidate set of core SRMNCAH indicators; and also the necessary buy-in needed from the sector to successfully nationally scale up, endorse and report against these indicators ${ }^{1}$.

\section{Desk review}

The project was initiated with a comprehensive review of peer-reviewed literature, existing published and unpublished data, including institutional and donor reports that focused on SRMNCAH indicators' reporting and analysis in Jordan; coupled with an in-depth examination of the national

Page $3 / 32$ 
SRMNCAH indicators' list that organizations are required to report against. This desk review also helped informed the selection of the target populations for each of the KIIs and FGDs.

\section{Field-level assessment (See Figure 1).}

Key Informant Interviews (KIIs): We compiled a list of key agencies working and providing SRMNCAH services to Syrian refugees across Jordan; as the majority of offices for these agencies were headquartered in Amman, we interviewed Kls individually or in small groups in Amman, Jordan. We conducted 10 KIls with 27 representatives from different entities including government entities, and national and international nongovernmental organizations between January and February 2020. Using a semi-structured interview guide developed specifically for the overarching study, we focused on KIs' perceptions and attitudes towards: SRMNCAH issues in Jordan, SRMNCAH service provision in Jordan for refugee populations, current reporting practices on SRMNCAH indicators, and the feasibility of reporting on the candidate set of core SRHMNAH indicators. We also explored stakeholders' perceptions and attitudes of current challenges in documenting and resources needed to successfully report against these indicators. We further explored the necessary buy-in needed among donor, governmental, and non-governmental agencies to enable the success of this effort.

Facility assessments: A list of facilities that provided RH services to Syrian refugees in Al-Za'atari camp, Irbid, and Karak was compiled by level (primary, secondary, and tertiary facilities). Each facility was informed, and WHO and United Nations Population Fund (UNFPA) country offices in Jordan facilitated the needed authorization prior to the evaluation. A total of five facility assessments were conducted. These assessments aimed to determine the nature and extent of SRMNCAH services offered, the ways in which patient information was collected, logged, stored, and safeguarded, and the types of human and technological resources used in data capture. In conjunction with the facility assessments, observational sessions were also carried out in all five facilities. These observational sessions aimed to assess existing resources currently being employed to collect data and additional resources needed to collect additional needed data for the core set of SRMNCAH indicators.

Focus group discussions: The facilities identified as the largest subsidized providers for SRMNCAH services for Syrian refugees in their respective governorates were selected for the FGDs. Five FGDs were conducted with 27 frontline workers from the same five agency health care clinics. Participants provided verbal consent at the beginning of each FGD, which lasted an average of 90 minutes and took place in Arabic. With consent, we audio-recorded all five FGDs, debriefed as a team after each discussion, and wrote analytic memos to capture group dynamics and identify early themes.

\section{Analytic approach}

An iterative, multi-phased approach was employed to analyse the data $(27,28)$. All KIls and FGDs were analysed for content and themes, using both inductive and deductive techniques, which were then combined with results from the facility assessments, validation discussions with KIs, and feedback from the WHO led to the final recommendations. The analysis focused on the four core elements: 1) feasibility of collecting the proposed core set of SRMNCAH indicators, 2) relevance and usefulness of SRMNCAH data management mechanisms; 3 ) availability of existing resources and systems for national and humanitarian SRMNCAH data collection; and 4) ethical considerations of collecting and storing data.

\section{Research Ethics}

The Research Project Review Panel (RP2) of WHO's Department of Sexual and Reproductive Health reviewed and approved this study. We also obtained authorization from the WHO's country office in Jordan and the Jordanian Ministry of Health (MoH). The Social Sciences and Humanities Research Ethics Board of the University of Ottawa provided ethical approval (Protocol number: S-08-18-1029).

${ }^{1} \mathrm{~A}$ more detailed description of this projects' methodology can be found in the report for the WHO.

\section{Findings}

The results of this assessment focused on the four core elements highlighted in the study objectives: 1) feasibility of collecting the proposed core set of SRMNCAH indicators, 2) relevance and usefulness of SRMNCAH data management mechanisms; 3) availability of existing resources and systems for national and humanitarian SRMNCAH data collection; and 4) ethical considerations. We first start by outlining the feasibility of the collecting the proposed SRMNCAH indicators, then we move to describing the current and potential advantages as well as challenges with SRMNCAH data capturing, followed by outlining the available data collections systems for the proposed indicators by the different humanitarian agencies. The findings section will conclude with discussing the different enforced measures in Jordan to protect data privacy and confidentiality among the different implementing agencies.

\section{1) Feasibility}


The findings of this assessment indicated that $48 \%$ of the proposed indicators were considered relevant and feasible to collect (see Table 1 ); many of the STI and RTI (100\%), newborn (81\%), contraception (75\%), maternal (53\%), and abortion (40\%) indicators were perceived to be relevant and feasible (see Table 1 and 2). Of these indicators recommended for inclusion; $45 \%$ of indicators, reportedly, are currently being collected and $14 \%$ of those that are not currently being collected were perceived to be able to be collected given resources and trainings (see Table 2). The findings also indicated that $48 \%$ of the proposed indicators were deemed unfeasible or irrelevant; especially indicators in child (30\%) and adolescent health (17\%), HIV, and prevention from mother to child (PMTC) (Table 2).

The findings from this assessment revealed that Jordan has multiple existing data collection information systems. These systems often compete with each other, which results in gaps in data collection and place undue burden on frontline staff. Lack of internal capacity and staffing impede the ability of organizations to develop and implement comprehensive computerized data capturing and reporting systems across health facilities. Frontline workers are required to report to multiple systems utilizing various templates and requiring different information. With this pre-existing arduous process in place, frontline workers expressed reticence at collecting a list of this length and perceived that the standardization of indicators is necessary to achieve feasibility of their data collection. While many perceived that some of the new proposed indicators in the framework could be easily integrated into existing systems for collection; the feasibility of collecting an indicator did not correlate with the relevance of the indicator, as participants highlighted that such data collection necessitates the availability of the needed resources to ensure the accuracy of the collected data. In Table 2, we provide an overview of the included and excluded list of indicators, the reported percentage of agencies who are currently collecting these indicators; sites of data collection; perceived facilitators and barriers for routine data collection; and any necessary modifications and resources necessary for routine data collection.

The results showed that three of the four proposed indicators on contraceptives were feasible to collect (indicators 1.1-3) given some wording modifications. The indicator connected to post abortion care (PAC) (indicator 1.4) was suggested for exclusion due to the legal status of abortion care in Jordan. It was indicated that policy and legislative changes are needed in parallel with training on the legal status and new IAFM guidelines along with VCAT sessions for frontline workers to make abortion indicators feasible for data collection in the Jordanian context.

The maternal health indicators were perceived as fairly feasible to collect, with the exception of indicators on service availability in the maternal health sector (indicators 3.9-12). Participants perceived that these indicators are not feasible to collect because of low burden of disease and sporadic service provision (indicators 3.13-16). Most of the proposed newborn health indicators relied on facility-based information and therefore are either being collected or were perceived to be easily feasible to be collected (indicators 4.1-8). Participants, however, expressed concerns surrounding the way that neonatal deaths and stillbirth are defined, recorded, and audited, particularly for cases outside of camps (indicators 4.12 ). On the other hand, participants expressed concerns over the feasibility of collecting a number of indicators related to child (indicators 5.2-6) and adolescent health (indicators 6.2-6), because these proposed indicators are population-level indicators and participants were concerned with impracticalities associated with measuring the needed denominators and/or the low burden of disease (indicators 5.7-9) in the local context.

Our findings suggested that significant gaps exist around data collection for sexual and gender-based violence (SGBV)-related indicators (indicators 7.2-7). Deep concerns were expressed that public reporting of SGBV information could result in a de-prioritization of efforts to expand clinical management of rape and GBV services. While none of the agencies that participated in this project are currently reporting any data on pregnancy outcomes for rape survivors or related abortion requests (indicator 7.5), participants felt this information could be collected if appropriate resources, ownership, supports and training were adequately set in place. Finally, participants raised concerns about the inclusion of any of the HIV/AIDS-related indicators (indicators 8.1-3 and 9.1-9.4) due to major stigma and discrimination from service providers, and the legislative barriers to providing care to refugees in Jordan who are screened positively with HIV/AIDs; in parallel with the low prevalence of disease in Jordan. We provide additional information about the specific indicators proposed for each topic in Table 2 and provide a detailed narrative for each domain of indicators in WHO's Jordan country-level report (available upon request).

\section{2) Relevance and usefulness of humanitarian SRMNCAH data management mechanisms}

\section{Perceived advantages with current and proposed SRMNCAH indicator reporting}

All the different participants in this assessment agreed that accurate and reliable SRMNCAH data provide the opportunity for implementing evidence-based programming, defining priorities, ensuring accountability among implementors. Hence, the majority of the proposed indicators were perceived to be essential in order to improve the health outcomes for both refugee and vulnerable communities in Jordan. In addition to the benefits of meeting the needs of refugee and vulnerable populations, our KIs noted that the collection and reporting of SRMNCAH indicators allows organizations to monitor and evaluate whether SRMNCAH services provided meet global and regional standards of care, population health goals, and donor reporting requirements. As noted by one $\mathrm{KI}$, "We can't capture everything, we have to be strategic with which indicators we select. We prioritize of course the indicators that contribute to our country program documents, the ones that align with the Sustainable Development Goals and of course to meet our reporting requirements [to donors]." 
However, stakeholders stressed the need for a core list of SRMNCAH indicators and encouraged that this same list to be used across all the different stakeholders simultaneously i.e. donors, the MoH, UN agencies, and international NGOs. In general, the stakeholders in all agencies supported the contours of the proposed core set of SRMNCAH indicators and noted that many of the specific indicators are aligned with many of their current and ongoing data collection practices and priorities. Stakeholders noted that across the board, that indicators derived from facilitylevel data were more relevant, useful, and practical to collect compared to those indicators that required information at the population level. As noted by an FGD participant, "The facility level indicators have both the potential to be more precise and really useful at the programmatic level in a way that population-level indicators tend to be harder to collect and are not necessarily accurate." Stakeholders also repeatedly asserted that having a standardized set for SRMNCAH indicators is important for advocacy-related activities, including establishing or amending policies to help increase access to services for refugee populations and supporting requests for increased funding.

\section{Perceived disadvantages with current SRMNCAH indicator reporting}

Our findings also indicated several disadvantages that could be associated with collecting some of the proposed SRMNCAH indicators. As noted by many of our stakeholders and FGD participants, a multitude of barriers contribute to the significant under reporting for SGBV cases in Jordan. For instance, many of the stakeholders felt that publishing the low numbers of rape and other reported SGBV-related cases would undermine the prioritization of those services, as this would be interpreted as lack of demand for this service. As one KI explained, "Recording the data [SGBV cases] is okay but presenting it as an indicator that may be published to external agencies? These small numbers can be misleading. They will argue you don't have a decent issue." Other indicators equally perceived as controversial were some of those related to the adolescent health, child health and HIV/AIDs.

\section{Perceived gaps in the proposed SRMNCAH indicators}

\section{Indicators that should be removed from the core set of SRMNCAH indicators}

Participants identified a number of the proposed indicators to either be not relevant or useful in the Jordanian context and therefore recommended their removal. The rationale for suggesting their exclusion, as per the KIs, revolved around one or more of the following: 1) the indicator relates to a condition for which there is low burden of disease in the Jordanian context; 2) national regulations and protocols restrict collecting information on the subject; 3 ) services related to the indicator are not (routinely) available; and/or 4) the indicator would not have any practical or actionable applications. Stakeholders were uniform in their belief that population-level indicators were not practical and could only be collected in conjunction with larger nationally representative surveys that take place every 5-10 years. More information on these specific indicators suggested for removal along with the reasons for removal can be found above in Table 3.

All Jordanian stakeholders raised concerns about the inclusion of HIV/AIDS-related indicators. Our KIs explained that due to national regulations and policies, all HIV/AIDS related cases must be referred to the $\mathrm{MoH}$ and foreigners who test positive for HIV are subject to immediate deportation - including refugees. Other indicators were deemed irrelevant because services are not routinely provided policies and regulations that hinder adequate capturing of data. These included indicators related to: comprehensive abortion care (CAC), syphilis screening, kangaroo mother care (KMC), and the LIVES ${ }^{2}$ intervention in cases of intimate partner violence. Indicators related to adolescent suicide rates and sexual violence against children were generally perceived as controversial for the participants of this study. KIs expressed that the indicator on suicide rate wouldn't be actionable and presents as an outlier from the core list of SRMNCAH indicators. The findings also suggest that indicators with population-level denominators should be removed and even if it could be collected, the data wouldn't inform programming due to, as it stands in Jordan, available population level data are unreliable.

\section{Additional Indicators that should be added to the core set of SRMNCAH indicators}

Stakeholders in Jordan also proposed some additional indicators for inclusion to the core SRMNCAH list. Those suggested indicators were mostly focused on adolescent sexual and reproductive health, supply-chains, commodities/stock outs, and coordination. Related to the issue of child/early marriage, both KIs and FGD participants felt that the proposed maternal death indicator needs to be further disaggregated by age, as the risk of maternal morbidity and mortality differed for those 15 years of age and under compared to those aged 16-18. On Fig. 2, we provide a list of additional topics that the Jordanian stakeholders perceived should be included on any core SRMNCAH indicator list.

\section{3) Existing systems and resources for collecting SRMNCAH indicators}

The findings from this assessment indicated that several robust health information systems are developed, implemented, and utilized by both international and national partner organizations in Jordan. In the last few years, there has been a significant national investment in the amelioration of national reporting systems for a subset of the proposed SRMNCAH domains, including systems for contraception, maternal

Page 6/32 
health, and SGBV. Access to comprehensive, user-friendly, computerized systems, necessary staff, and capacity varied across agencies. As a result, agencies often had to input and analyze their data manually, impacting accurate, standardized, and timely data reporting. Although, a number of organizations have built their own dedicated HIS internally, not all agencies have access to the same level of funding and/or the same human and technological capacities, meaning that some agencies are working with less contextually developed systems. We provide a list of the available data collection resources and systems reported by our stakeholders in Table 4.

\section{4) Ethical considerations}

The findings from the KIIs, FGDs and facility assessments suggested that there are inconsistent and fragmented efforts for data protection and confidentiality surrounding SRMNCAH data and research across the different humanitarian agencies in Jordan. Health care facilities have basic protocols in place for data logging and protection, especially surrounding GBV data and access to the gender-based violence information management system (GBVMIS). However, the availability of data privacy and confidentiality protocols was directly correlated with the resources allocated for data collection and protection. Many agencies were able to run health care clinics and allocated funding to specialized Monitoring, Evaluation, Accountability and Learning (MEAL) departments and staff, institutional protocols, and a comprehensive HIS; yet, the majority of the health facilities we visited $(n=4)$ utilized Microsoft Excel for delivering and storing data. This was done mainly on an institution's computer with a fixed password, an e-mail, a USB flash memory, or even tally-sheet printouts or the use of mobile phones. Some of the facilities visited kept a manual patient logbook could be accessed by 'any' staff member ( $n=2)$, while the remaining facilities ( $n=3$ ) had specific (often the head nurse or midwife) on shift who had access to the master patient logbook.

All of our stakeholders discussed concerns with confidentiality and the national mandatory reporting requirements for GBV and early marriage. Participants explained that humanitarian organizations working in Jordan are mandated to abide by the country's laws and regulations. This further exacerbates the underreporting of SGBV and early marriage cases for refugees residing in Jordan (29). Similar challenges were noted surrounding the reporting of HIV and PMTCT-related indicators. Given that refugees face deportation if they are diagnosed with HIV (30), stakeholders had deep concerns about confidentiality, and most do not keep internal records. As a participant explained,

We inform them [the HIV positive refugee] that we will have what we call a gentleman's agreement with the MOH. When it comes to that refugee, if he or she found to be positive, we inform them that we will find a durable solution for the case, and that's resettlement. So, they wait for us, until we get the settlement ${ }^{3}$ for the case.

${ }^{2}$ LIVES Model developed by the World Health Organization: Includes a first-line support that involves five simple tasks; 1 ) Listen to the woman closely, with empathy, and without judging; 2) Inquire about needs and concerns, assess and respond to her various needs and concernsemotional, physical, social and practical (eg.childcare); 3) Validate, show her that you understand and believe her. Assure her that she is not to blame; 4) Enhance Safety, discuss a plan to protect herself from further harm if violence occurs again; and 5) Support her by helping her connect to information, services and social support (32).

${ }^{3}$ UNHCR will work to resettle any refugee who is HIV positive outside of Jordan to receive HIV-AIDS related services and treatment.

\section{Discussion}

The findings from this multi-methods feasibility assessment provide a comprehensive overview of the feasibility of collecting a core set of SRMNCAH indicators in the humanitarian context of Jordan for improved humanitarian response. The outlined recommendations are steppingstones for SRMNCAH service and outcomes monitoring and evaluation in humanitarian settings. The recommendations also aid communities, donors, and humanitarian actors in creating an enabling environment for quality SRMNCAH data collectoion and evidence-based decision making. In Figure 3, we outline the policy, strategy, capacity, training, HR, and communication factors that are supported by the literature that need to be implemented and addressed at the global and national, programmatic and facility levels to increase the feasibility of current indicator reporting practices and the quality of SRMNCAH data reporting $(13,15,31-34)$.

With a three-tiered health care system ${ }^{4}$, limited budgets and varying policies and regulations in Jordan (35), the development of national priorities and guidelines for improving SRMNCAH indicators' reporting for its population - and for refugee populations more specifically - has proven to be challenging. The literature indicates that despite the surfeit of data requested by the overarching humanitarian structure, researchers have found systematic reporting gaps for different SRMNCAH programming and evidence for impact on SRMNCAH and outcomes (16, 36, 37). In 2014, Obrégon and colleagues concluded that there were major gaps in basic information needed to assess the quality and context of the data and reports they reviewed were lacking, irrespective of state of emergency or region (36). A noted challenge to this by the research respondents, is that the requested data collection from donors, the national government, international and United Nations (UN) agencies, coordination/cluster systems is highly variable and burdensome. This is further complicated with a three-tiered health care system ${ }^{5}$, limited budgets and varying policies and regulations in Jordan (35), which often rendered the development of national priorities and guidelines for improving SRMNCAH 
indicators' reporting for its population-and for refugee populations more specifically-to be challenging. A mixed-methods assessment of routine health information systems and data conducted in Addis Ababa found that the extensive presence of parallel reporting and unstandardized routine data collection practices resulted in over and under reporting of health indicators and had negative implications on service provider's perceptions toward routine health data collection practice; impacting data completeness and quality (38). Jordanian stakeholders were clear that this core set of indicators would only be useful with buy-in from the global community that results in harmonizing and coordinating data collection efforts and relevant indicators' reporting requirements. The literature outlines the incompatibility between decentralized humanitarian organizational structure (i.e., allowing for a high degree of independence for sub and field offices, with minimal oversight by the headquarter (HQ), including HQ's HIS infrastructure (17). The availability of a robust computerized system will therefore directly depend on the budget and prioritization of monitoring systems (39), combined with a focus om preventing standardized horizontal communication and encouraging coordination efforts between and within different agencies (17). Therefore, the sustainability of these data collection systems is directly dependent on the agencies' and donors' willingness to provide regular and continuous multi-year funding for national and international organizations, which currently is often crippled.

Stakeholders were clear that collecting the SRMNCAH indicators that required a population-level denominator may not be often feasible, particularly in urban environments. More than $70 \%$ of all Syrian refugees in Jordan reside outside of camps (1). Although, these populations are concentrated in some areas, this population was only fully counted after completion of the most recent Jordan Population and Family and Health Survey (JPFHS), the results of which were published in 2018 (40). Participants noted that the Demographic and Health Survey Program cycle is pre-determined. It requires significant resources and should continue to be collected and coordinated at the national level, which could impact the data quality of those indicators that rely on population level denominators. Study participants repeatedly emphasized their preference for a core set of facility-based indicators, as they perceived them to be more programmatically relevant and actionable. Guha-Sapir and Scales (2020) found that the use of facility-based data, preferably in the form of patient records, improved data analysis and quality, and strengthens the estimation of mortality and morbidity in emergency settings (41). The study findings also suggest that facility-based indicators could be used as proxies to reflect recognized services delivery standards of SRMNCAH care in humanitarian settings, as most are pertinent to the Minimum Initial Services Package (MISP). Hence, for those indicators, even if they were not currently being collected, KIls and FGD participants could generally envision how to incorporate this information into the facility-level data collection systems.

Our findings also indicated that there are socio-political as well as cultural barriers that could impede the collection of certain SRMNCAH indicators, specifically those surrounding sexual and gender-based violence (SGBV), abortion, and HIV/AIDs domains of indicators. A study exploring barriers of reporting of sexual violence in Al-Za'atari camp found that Syrian women did not report these cases, due to shame, limited trust in helpers and a strained legal framework (29). The literature shows that mobilizing innovative and validated methods such as "the Neighbourhood method" for estimating prevalence rates with an accuracy could be a suitable alternative for programmatic purposes in conflictaffected and post-conflict settings (42). Adopting novel approaches for estimating abortion incidence could also help mitigate the socio-cultural barriers to access, disclosure and reporting (43).

Stakeholders raised concerns about the inclusion of all the HIV/AIDS-related indicators due to major stigma and discrimination from service providers, as national reporting and treatment protocols preclude organizations from collecting data on HIV and prevention of mother-to-child transmission (PMTCT) $(30,44)$. According to the Jordanian legislative system, medical professionals and health facilities are mandated to report an individual's HIV status to the government (30); foreign nationals, including refugees, who are found to be HIV-positive, are deported regardless of the consequences to their health and safety, and are not permitted to return to Jordan (44). This highlights the need to reflect on the ethical implications; while considering the inclusion of these indicators. As, requiring reporting of HIV data without stringent protocols for data protection will only serve to increase stigma, which has been shown to delay enrolment in care for people living with HIV (30).

Given the need for consistency and accountability for monitoring and evaluation of SRMNACH services and outcomes in humanitarian settings, WHO, in collaboration with partner agencies, has supported the development of a 'Data and Accountability Roadmap for Improving Data, Monitoring and Accountability for SRH in Crises' (33). This Roadmap responded to the need for collecting, aggregating, making accessible, using clear and consistent data; aligning with the SDGs, the 'Every Women Every Child Strategy', and the commitments made at the 2017 Family Planning Summit to address data gaps. The roadmap combined with data literacy and indicator management awareness, digital aid frameworks and amendments of laws and regulations should be prioritized at the national and programmatic level to create an enabling environment to reduce duplicity, and improve communication channels and overarching SRMNCAH data quality (45).

The findings from our assessment also indicated the need for resources, training, and capacity building to enhance the feasibility of accurate and ethical reporting on the proposed list of SRMNCAH indicators. An array of trainings accompanied with a tool kit guide on data collection for each of the SRMNCAH indicators' domains is necessary before the rollout of the proposed indicators. The Jordanian context requires a centralized Health Information System that is harmonized and adequately coordinated with global and national reporting requirements to prevent overburdening staff at the data-collection level (32). The system should be developed and tailored for use in the local context (11) as in the past, many data collection systems that were specifically designed for humanitarian actors were actually utilized in national systems with field workers. There should be a sustainable funded effort at the facility-level to update data collection systems and adapt medical records and 
logbooks, in order to create standardized data collection fields for the information derived from patient medical records. There must be capacity building at government-run organizations and local clinics to clean, correct, and annotate data.

${ }^{4}$ Health care services in Jordan are provided through the public/semipublic and private sector, and through Jordan's Royal Medical Services (RMS). Services are provided through hospitals, primary care clinics, pharmacies and other ancillary services. In addition to the sectors, a significant portion of health services are provided through programs led by the United Nations and other international and national nongovernmental humanitarian agencies.

${ }^{5}$ Health care services in Jordan are provided through the public/semipublic and private sector, and through Jordan's Royal Medical Services (RMS). Services are provided through hospitals, primary care clinics, pharmacies and other ancillary services. In addition to the sectors, a significant portion of health services are provided through programs led by the United Nations and other international and national nongovernmental humanitarian agencies.

\section{Strengths And Limitations}

The strategies recommended by Guba (46) were used for evaluating the trustworthiness of the data in this assessment. Credibility, confirmability, and transferability were used to ensure the trustworthiness of the data. Prolonged engagement, triangulation, member checks, peer-debriefing with the study team in both Jordan and Canada were used to ensure the credibility of the data (47). The mixed-methods design of this study enabled the integration of data from multiple sources. Qualitative data was used to explore and explain the quantitative findings, with the findings from the facility assessments also validating (or in some cases dispelling) key themes identified in analyses of FGDs and KIls. The facility assessments provided important findings relating to current management SRMNCAH monitoring and evaluation systems as well as the availability and distribution of specific resources. Despite these strengths, however, our study was limited by challenges with documentation, for example, despite extensive efforts, it was not always possible to locate and access SRMNCAH monitoring and evaluation records. The positionalities of the research team members undoubtedly influenced the participant-researcher interaction as well as our interpretation of data collected. Through memoing and regular debriefings, we attempted to reflect on and understand these dynamics, thereby enhancing the credibility and trustworthiness of the findings.

\section{Conclusion}

The findings from our multi-methods feasibility assessment suggest that, overall, there is widespread support for developing a core and concise list of SRMNCAH indicators among humanitarian stakeholders in Jordan. Representatives from a variety of institutions noted numerous already existent resources and systems that could be leveraged, built upon, and improved to ensure the feasibility of collecting this core set of indicators for monitoring and SRMNCAH services and outcomes in humanitarian settings in Jordan. However, an important challenge to this was noted by the research respondents, which was that the requested data collection from donors, the national government, international and UN agencies, coordination/cluster systems is highly variable and burdensome. Jordanian stakeholders were clear that this core set of SRMNCAH indicators can only be useful, if buy-in from the global community to harmonize and coordinate data collection efforts and relevant indicators' reporting requirements is ensured.

\section{List Of Abbreviations}

BEmOC Basic emergency obstetrical care

CEmOC Comprehensive emergency obstetrical care

FGD Focus Group Discussions

HIS Health Information System

GBVMIS gender-based violence information management system

HIV/AIDS Human Immunodeficiency Virus/ Acquired immunodeficiency syndrome

IAFM Inter-Agency Field Manual on Reproductive Health

KI Key Informant

KII Key Informant Interview

KMC Kangaroo mother care 
MEAL Monitoring, Evaluation, Accountability and Learning

MISP Minimum Initial Service Package

MoH Ministry of Health

NGO Non-governmental organization

NSRHFP National Strategy for Reproductive Health and Family Planning

PAC/CAC Post abortion care/Comprehensive abortion care

RP2 Research Project Review Panel

SGBV Sexual and gender-based violence

SRH Sexual and reproductive health

SRMNCAH Sexual, reproductive, maternal, neonatal, child, and adolescent health

UN United Nations

UNFPA United Nations Population Fund

UNHCR United Nations High Commissioner for Refugees

UNICEF United Nations Children's Fund

VCAT Values clarification and attitudes transformation

WHO World Health Organization

\section{Declarations}

Ethics approval and consent to participate

See Methods

Consent for publication

Not applicable

Availability of data and material

Available upon request

Competing interests

The authors declare that they have no competing interests. The authors alone are responsible for the views expressed in this article and they do not necessarily represent the views, decisions or policies of the institutions with which they are affiliated.

\section{Funding}

This work was funded by the Department of Sexual and Reproductive Health and Research (SRH), including the UNDP/UNFPA/UNICEF/WHO/World Bank Special Programme of Research, Development and Research Training in Human Reproduction (HRP) and the Department of Maternal, Newborn, Child and Adolescent Health and Ageing (MCA). The funders had no role in study design, data collection and analysis, decision to publish, or preparation of the manuscript.

\section{Authors' contributions}

LK, MS, IM, AF developed the study protocol, carried out the literature search, cleaning and data management and analysis, MS, IM, AF led the data collection processes in the field. KA, KE, AA, MS, IM, LK assisted with data analysis. IM, LK, KA, KE, AA, and EK were major contributors in writing the manuscript. All authors IM, LK, KA, KE, AA, AF, MH, and EK edited, read and approved the final manuscript. 
To all colleagues at WHO and UNFPA country offices in Jordan, as well as at the regional offices in Egypt who facilitated access to the desired target population, field, data collection as well as informed the interpretation and the understanding of the assessment findings. Thank you to all the students from Dr. Angel M. Foster's lab that worked on the transcriptions and data cleaning. To all our assessment target participants whose opinions, experience and expertise made this assessment possible.

\section{References}

1. UNHCR. Situation Syria Regional Refugee Response [Internet]. Operational Data Portal- Refugee Situation. 2021 [cited 2021 Nov 6]. Available from: https://data2.unhcr.org/en/situations/syria/location/36

2. Gausman J, Othman A, Hamad IL, Dabobe M, Daas I, Langer A. How do Jordanian and Syrian youth living in Jordan envision their sexual and reproductive health needs? A concept mapping study protocol. BMJ Open. 2019 Jan 1;9(1).

3. Ghazal M. Jordan hosts 657,000 registered Syrian refugees | Jordan Times. Jordan Times [Internet]. 2017 [cited 2018 May 27 ]; Available from: http://www.jordantimes.com/news/local/jordan-hosts-657000-registered-syrian-refugees

4. Krause S, Williams H, Onyango MA, Sami S, Doedens W, Giga N, et al. Reproductive health services for Syrian refugees in Zaatri Camp and Irbid City, Hashemite Kingdom of Jordan: an evaluation of the Minimum Initial Services Package. Confl Health [Internet]. 2015;9(Suppl 1):S4. Available from: http://conflictandhealth.biomedcentral.com/articles/10.1186/1752-1505-9-S1-S4

5. Inter-Agency. Gender-based Violence and Child Protection among Syrian Refugees in Jordan, with a Focus on Early Marriage [Internet]. 2013 [cited 2021 Nov 6]. Available from: https://www.refworld.org/docid/52cfa5d14.html

6. Ay M, Arcos González P, Castro Delgado R. The Perceived Barriers of Access to Health Care Among a Group of Non-camp Syrian Refugees in Jordan. Int J Heal Serv [Internet]. 2016 Jul 9 [cited 2018 May 27];46(3):566-89. Available from:

http://www.ncbi.nlm.nih.gov/pubmed/26962004

7. Gausman J, Othman A, Hamad IL, Dabobe M, Daas I, Langer A. How do Jordanian and Syrian youth living in Jordan envision their sexual and reproductive health needs? A concept mapping study protocol. BMJ Open [Internet]. 2019 Jan 1 [cited 2021 Nov 6];9(1):e027266. Available from: https://bmjopen.bmj.com/content/9/1/e027266

8. European Union. Expanding and Equipping the Ministry of health facilities impacted by the Syrian crisis in Jordan. 2018.

9. Banatvala N, Zwi AB. Conflict and health: Public health and humanitarian interventions: developing the evidence base. BMJ Br Med J [Internet]. 2000 Jul 8 [cited 2021 Nov 6];321(7253):101. Available from: /pmc/articles/PMC1127723/

10. M A, IM E-M, T C, H Y, LH K. An overview of the sexual and reproductive health status and service delivery among Syrian refugees in Jordan, nine years since the crisis: a systematic literature review. Reprod Health [Internet]. 2020 Dec 1 [cited 2021 Nov 6];17(1). Available from: https://pubmed.ncbi.nlm.nih.gov/33115474/

11. Alexander Betts, Louise Bloom, Josiah Kaplan and NO. Refugee Economies: Forced Displacement and Development. 1st ed. Oxford University Press; 2016.

12. Jacobsen K. The economic life of refugees [Internet]. Kumarian Press; 2005 [cited 2021 Nov 6]. 131 p. Available from: https://books.google.com/books/about/The_Economic_Life_of_Refugees.html?id=TFtPwOFZOnAC

13. Schön AM, Al-Saadi S, Grubmueller J, Schumann-Bölsche D. Developing a camp performance indicator system and its application to Zaatari, Jordan. J Humanit Logist Supply Chain Manag. 2018 Oct 17;8(3):346-73.

14. OCHA. Overview of Global Humanitarian Response 2014 [Internet]. ReliefWeb. 2013 [cited 2021 Nov 6]. Available from: https://reliefweb.int/report/world/overview-global-humanitarian-response-2014-enfres

15. Ogbu TJ, Guha-Sapir D. Strengthening data quality and reporting from small-scale surveys in humanitarian settings: a case study from Yemen, 2011-2019. Confl Health. 2021;15(1):1-8.

16. Broaddus-Shea ET, Kobeissi L, Ummer O, Say L. A systematic review of monitoring and evaluation indicators for sexual and reproductive health in humanitarian settings. Confl Health [Internet]. 2019 Oct 14 [cited 2021 Mar 9];13(1):43. Available from: https://conflictandhealth.biomedcentral.com/articles/10.1186/s13031-019-0221-1

17. Altay N, Labonte M. Challenges in humanitarian information management and exchange: evidence from Haiti. Disasters [Internet]. 2014 Apr 1 [cited 2021 Nov 6];38(s1):S50-72. Available from: https://onlinelibrary.wiley.com/doi/full/10.1111/disa.12052

18. Harvard International Review. Effective Aid: Ensuring Accountability in Humanitarian Assistance [Internet]. Hardvard Review. 2013 [cited $2021 \mathrm{Mar}$ 9]. Available from: https://hir.harvard.edu/effective-aid/

19. Ahmed M. Effective Humanitarian Information Systems [Internet]. [IOWA]: IOWA State University; 2021 [cited 2021 Nov 6]. Available from: https://lib.dr.iastate.edu/creativecomponents 
20. Pyone T, Dickinson F, Kerr R, Boschi-Pinto C, Mathai M, Van den Broek N. Data collection tools for maternal and child health in humanitarian emergencies: a systematic review [Internet]. Vol. 93, Bulletin of the World Health Organization. World Health Organization; 2015 [cited 2021 Mar 9]. p. 648A-658A. Available from: /pmc/articles/PMC4581640/

21. Development Initiatives, OCHA, IASC, HFTT. Improving humanitarian transparency with the International Aid Transparency Initiative (IATI) and the UN OCHA Financial Tracking Service (FTS) . 2017.

22. Gazi T. Data to the rescue: how humanitarian aid NGOs should collect information based on the GDPR. J Int Humanit Action [Internet]. 2020 Dec 16 [cited 2021 Mar 9];5(1):9. Available from: https://jhumanitarianaction.springeropen.com/articles/10.1186/s41018-020-00078-0

23. Foster MA, El-Mowafi MI. Assessment of the 2013-2018 National Strategy for Reproductive Health and Family Planning [Internet]. Amman; 2019 [cited 2021 Mar 9]. Available from: https://www.worldvision.org/refugees-news-stories/syrian-refugee-crisis-facts

24. Klaib AF, Nuser MS. Evaluating EHR and health care in Jordan according to the international health metrics network (HMN) framework and standards: A case study of hakeem. IEEE Access. 2019;7:51457-65.

25. Sphere Association. The Sphere Handbook Humanitarian Charter and Minimum Standards in Humanitarian Response [Internet]. 2018 [cited 2021 Mar 9]. Available from: www.practicalactionpublishing.org/sphere

26. Inter-Agency Standing Committee. Guidelines for Integrating Gender-Based Violence Interventions in Humanitarian Action: Reducing Risk, Promoting Resiliewnce and Aiding Recovery [Internet]. 2015. [cited 2021 Mar 9]. Available from:

https://interagencystandingcommittee.org/working-group/iasc-guidelines-integrating-gender-based-violence-interventions-humanitarianaction-2015

27. Denzin NK, Lincoln YS. The Sage handbook of qualitative research, 3rd ed. Denzin NK, Lincoln YS, editors. The Sage handbook of qualitative research, 3rd ed. Thousand Oaks, CA: Sage Publications Ltd; 2005. xix, 1210-xix, 1210.

28. Elo S, Kyngäs H. The qualitative content analysis process. J Adv Nurs [Internet]. 2008 Apr 1 [cited 2020 Mar 11];62(1):107-15. Available from: http://doi.wiley.com/10.1111/j.1365-2648.2007.04569.x

29. Mactavish E. Running head: BARRIERS OF REPORTING SEXUAL VIOLENCE IN SYRIAN REFUGEE CAMPS Barriers of Reporting Sexual Violence in Syrian Refugee Camps. [Victoria]: Royal Roads University; 2016.

30. Martini M, Elmalak L. HIV and AIDS and the World of Work: Legislative Framework Review for Jordan "Analysis and Priority-Setting in relation to Law and Practice on HIV and AIDS and the World of Work in Jordan" [Internet]. 2013 [cited 2021 Nov 8]. Available from: www.ilo.org/publns

31. Malilay J, Flanders WD, Brogan D. A modified cluster-sampling method for post-disaster rapid assessment of needs. Bull World Health Organ [Internet]. 1996 [cited 2021 Nov 8];74(4):399. Available from: /pmc/articles/PMC2486880/?report=abstract

32. Kågesten AE, Tunçalp Ö, Portela A, Ali M, Tran N, Gülmezoglu AM. Programme Reporting Standards (PRS) for improving the reporting of sexual, reproductive, maternal, newborn, child and adolescent health programmes. BMC Med Res Methodol. 2017 Aug 3;17(1).

33. Saliba D, Solomon D, Rubenstein L, Young R, Schnelle J, Roth C, et al. Feasibility of quality indicators for the management of geriatric syndromes in nursing home residents. J Am Med Dir Assoc [Internet]. 2005 May [cited 2021 Nov 8];6(3 Suppl):S50-9. Available from: https://pubmed.ncbi.nlm.nih.gov/15890298/

34. Koek I, Monclair M, Anastasi E, Ten Hoope-Bender P, Higgs E, Obregon R. Doing What We Do, Better: Improving Our Work Through Systematic Program Reporting. Glob Heal Sci Pract [Internet]. 2018 Jun 27 [cited 2021 Nov 8];6(2):257-9. Available from: https://www.ghspjournal.org/content/6/2/257

35. Jalghoum Y, Tahtamouni A, Khasawneh S, Al-Madadha A. Challenges to healthcare information systems development: The case of Jordan. Int J Healthc Manag [Internet]. 2019 [cited 2021 Feb 8]; Available from: https://www.tandfonline.com/action/journallnformation? journalCode=yjhm20

36. Fox E, Obregón R. Population-level behavior change to enhance child survival and development in low-and middle-income countries. J Health Commun. 2014 May 13;19:3-9.

37. IAWG. Reproductive Health in the Changing Humanitarian Context: Findings from the IAWG on Reproductive Health in Crises' $2012-2014$ Global Evaluation | Inter-Agency Working Group on Reproductive Health in Crises [Internet]. 2016 [cited 2021 Mar 9]. Available from: https://iawg.net/resources/global-evaluation-2014

38. Haftu B, Taye G, Ayele W, Biruk E, Habtamu T. A Mixed-Methods Assessment Of Routine Health Information System (RHIS) Data Quality And Factors Affecting It, Addis Ababa City Administration, Ethiopia, 2020. 2021 Jul 15;

39. Blanchet K, Ramesh A, Frison S, Warren E, Hossain M, Smith J, et al. Evidence on public health interventions in humanitarian crises. Lancet [Internet]. 2017 Nov 18 [cited 2021 Nov 8];390(10109):2287-96. Available from: http://www.thelancet.com/article/S0140673616307681/fulltext

40. Population J, Survey FH. THE HASHEMITE KINGDOM OF JORDAN [Internet]. 2017 [cited 2019 Jun 6]. Available from: www.DHSprogram.com.

Page $12 / 32$ 
41. Guha-Sapir D, Scales SE. Challenges in public health and epidemiology research in humanitarian settings: experiences from the field. BMC Public Health [Internet]. 2020 Dec 1 [cited 2021 Nov 8];20(1):1-6. Available from: https://bmcpublichealth.biomedcentral.com/articles/10.1186/s12889-020-09851-7

42. Stark L, Landis D, Thomson B, Potts A. Navigating support, resilience, and care: Exploring the impact of informal social networks on the rehabilitation and care of young female survivors of sexual violence in Northern Uganda. Peace Confl. 2016;22(3):217-25.

43. Sedgh G, Keogh SC. Novel approaches to estimating abortion incidence. Reprod Health [Internet]. 2019 Apr 18 [cited 2021 Nov 8];16(1):1-10. Available from: https://reproductive-health-journal.biomedcentral.com/articles/10.1186/s12978-019-0702-0

44. Gökengin D, Doroudi F, Tohme J, Collins B, Madani N. HIV/AIDS: trends in the Middle East and North Africa region. Int J Infect Dis. 2016 Mar $1 ; 44: 66-73$.

45. Utilization of telecommunications for disaster preparedness mitigation and response. International Telecommunication Union [Internet]. 2017 [cited 2021 Nov 8]. Available from: https://www.itu.int/pub/D-STG-SG02.05.1-2017

46. Guba EG. Criteria for assessing the trustworthiness of naturalistic inquiries. Educ Commun Technol. 1981 Jun;29(2):75-91.

47. Anney VN. Ensuring the quality of the findings of qualitative research: Looking at trustworthiness criteria. J Emerg Trends Educ Res Policy Stud [Internet]. 2014 [cited 2021 Nov 9];5(2):272-81. Available from: http://196.44.162.10:8080/xmlui/handle/123456789/256

48. CATIE. Service mapping: one approach to building strong programs [Internet]. 2016 [cited 2021 Mar 10]. Available from: https://www.catie.ca/en/pif/service-mapping-one-approach-building-strong-programs

\section{Tables}

Table 1

Summary and percentage of the indicators by domain that were perceived relevant and to the Jordanian context, by number and percentage

\begin{tabular}{|c|c|c|c|}
\hline & $\begin{array}{l}\text { Number of indicators } \\
\text { by domain (n) }\end{array}$ & $\begin{array}{l}\text { Number of indicators relevant to the } \\
\text { Jordanian context (n) }\end{array}$ & $\begin{array}{l}\% \text { of indicators that } \\
\text { are feasible }\end{array}$ \\
\hline Contraception & 4 & 3 & $75 \%$ \\
\hline Comprehensive Abortion Care & 5 & 2 & $40 \%$ \\
\hline Maternal Health & 17 & 9 & $53 \%$ \\
\hline Newborn Health & 16 & 13 & $81 \%$ \\
\hline Child Health & 10 & 3 & $30 \%$ \\
\hline Adolescent health & 6 & 1 & $17 \%$ \\
\hline Sexual and gender-based violence & 7 & 3 & $14 \%$ \\
\hline HIV & 3 & 0 & $0 \%$ \\
\hline Prevention from Mother to Child & 4 & 0 & $0 \%$ \\
\hline $\begin{array}{l}\text { Sexually transmitted infections (STIs) \& } \\
\text { reproductive tract infections (RTIs) }\end{array}$ & 1 & 1 & $100 \%$ \\
\hline Total & 73 & 35 & $48 \%$ \\
\hline
\end{tabular}


Table 2

Summary findings of the feasibility of collecting the following proposed SRMNCAH indicators in the humanitarian context of Jordan

\begin{tabular}{|c|c|c|c|c|c|c|c|c|}
\hline No. & Indicator name & $\begin{array}{l}\text { Overall \% } \\
\text { of } \\
\text { Agencies } \\
\text { Reporting }\end{array}$ & $\begin{array}{l}\text { Place of } \\
\text { Collection }\end{array}$ & $\begin{array}{l}\text { Facilitators } \\
\text { to Routine } \\
\text { Collection }\end{array}$ & $\begin{array}{l}\text { Barriers to } \\
\text { Routine } \\
\text { Collection }\end{array}$ & $\begin{array}{l}\text { Necessary } \\
\text { Modifications }\end{array}$ & $\begin{array}{l}\text { Resources } \\
\text { Needed for } \\
\text { Routine } \\
\text { Collection }\end{array}$ & Exclude/Include \\
\hline \multicolumn{9}{|c|}{ Contraception } \\
\hline 1.1 & $\begin{array}{l}\text { Number of } \\
\text { clients } \\
\text { initiating } \\
\text { contraception }\end{array}$ & $60 \%$ & $\begin{array}{l}\text { Health } \\
\text { facilities, } \\
\text { primary, } \\
\text { and } \\
\text { secondary } \\
\text { health } \\
\text { services }\end{array}$ & $\begin{array}{l}\text { National } \\
\text { Reporting } \\
\text { System: } \\
\text { centralized } \\
\text { system in the } \\
\text { MoH, NSSRH } \\
\text { (Higher } \\
\text { Population } \\
\text { Council) }\end{array}$ & $\begin{array}{l}\text { Insufficient } \\
\text { security and } \\
\text { privacy } \\
\text { measures set } \\
\text { in place }\end{array}$ & $\begin{array}{l}\text { Clarification } \\
\text { on the } \\
\text { wording } \\
\text { surrounding } \\
\text { "initiating" - } \\
\text { standardize } \\
\text { definition of } \\
\text { new user vs. } \\
\text { recurrent } \\
\text { user. }\end{array}$ & $\begin{array}{l}\text { Resources and } \\
\text { training } \\
\text { regarding } \\
\text { security \& data } \\
\text { privacy }\end{array}$ & Include \\
\hline 1.2 & $\begin{array}{l}\text { Number of } \\
\text { clients } \\
\text { receiving } \\
\text { emergency } \\
\text { contraception }\end{array}$ & $20 \%$ & $\begin{array}{l}\text { Health } \\
\text { facilities, } \\
\text { primary, } \\
\text { and } \\
\text { secondary } \\
\text { health } \\
\text { services }\end{array}$ & $\begin{array}{l}\text { National } \\
\text { Reporting } \\
\text { System: } \\
\text { centralized } \\
\text { system in the } \\
\text { MoH, NSSRH } \\
\text { (Higher } \\
\text { Population } \\
\text { Council) }\end{array}$ & $\begin{array}{l}\text { No } \\
\text { availability } \\
\text { of } \\
\text { commodity: } \\
\text { No dedicated } \\
\text { emergency } \\
\text { contraceptive } \\
\text { (EC) pill } \\
\text { registered in } \\
\text { Jordan } \\
\text { Insufficient } \\
\text { security and } \\
\text { privacy } \\
\text { measures set } \\
\text { in place }\end{array}$ & $\mathrm{N} / \mathrm{A}$ & $\begin{array}{l}\text { Training on } \\
\text { new IAFM } \\
\text { guidelines } \\
\text { Training } \\
\text { providers on } \\
\text { the different } \\
\text { contraceptive } \\
\text { modalities that } \\
\text { can be used for } \\
\text { EC } \\
\text { Resources and } \\
\text { training } \\
\text { regarding } \\
\text { security and } \\
\text { data privacy }\end{array}$ & Include \\
\hline 1.3 & $\begin{array}{l}\text { Percentage of } \\
\text { clients } \\
\text { adopting } \\
\text { modern } \\
\text { contraceptive } \\
\text { method after } \\
\text { delivery }\end{array}$ & $60 \%$ & $\begin{array}{l}\text { Health } \\
\text { facilities, } \\
\text { primary, } \\
\text { and } \\
\text { secondary } \\
\text { health } \\
\text { services }\end{array}$ & $\begin{array}{l}\text { National } \\
\text { Reporting } \\
\text { System: } \\
\text { centralized } \\
\text { system in the } \\
\text { MoH, NSSRH } \\
\text { (Higher } \\
\text { Population } \\
\text { Council) }\end{array}$ & $\begin{array}{l}\text { Current } \\
\text { collection } \\
\text { occurring } \\
\text { during PNC } \\
\text { visit not at } \\
\text { discharge } \\
\text { Insufficient } \\
\text { security and } \\
\text { privacy } \\
\text { measures set } \\
\text { in place }\end{array}$ & $\begin{array}{l}\text { Clarification } \\
\text { on the } \\
\text { wording } \\
\text { surrounding } \\
\text { "initiating" - } \\
\text { standardize } \\
\text { definition of } \\
\text { new user vs. } \\
\text { recurrent } \\
\text { user. }\end{array}$ & $\begin{array}{l}\text { Resources and } \\
\text { training } \\
\text { regarding } \\
\text { security \& data } \\
\text { privacy }\end{array}$ & Include \\
\hline 1.4 & $\begin{array}{l}\text { Percentage of } \\
\text { clients } \\
\text { adopting } \\
\text { modern } \\
\text { contraceptive } \\
\text { method after } \\
\text { abortion }\end{array}$ & $0 \%$ & $\mathrm{~N} / \mathrm{A}$ & $\begin{array}{l}\text { National } \\
\text { Reporting } \\
\text { System: } \\
\text { centralized } \\
\text { system in the } \\
\text { MoH, NSSRH } \\
\text { (Higher } \\
\text { Population } \\
\text { Council) }\end{array}$ & $\begin{array}{l}\text { Legal status } \\
\text { of abortion in } \\
\text { Jordan } \\
\text { Service not } \\
\text { provided } \\
\text { Insufficient } \\
\text { security and } \\
\text { privacy } \\
\text { measures set } \\
\text { in place }\end{array}$ & $\mathrm{N} / \mathrm{A}$ & $\mathrm{N} / \mathrm{A}$ & Exclude \\
\hline \multicolumn{9}{|c|}{ Comprehensive abortion care } \\
\hline 2.1 & $\begin{array}{l}\text { Number of } \\
\text { clients } \\
\text { requesting an } \\
\text { abortion }\end{array}$ & $0 \%$ & $\mathrm{~N} / \mathrm{A}$ & $\mathrm{N} / \mathrm{A}$ & $\begin{array}{l}\text { Legal status } \\
\text { of abortion in } \\
\text { Jordan } \\
\text { Potential risk } \\
\text { for client and } \\
\text { primary care } \\
\text { provider } \\
\text { Insufficient } \\
\text { security and } \\
\text { privacy } \\
\text { measures set } \\
\text { in place }\end{array}$ & $\mathrm{N} / \mathrm{A}$ & $\mathrm{N} / \mathrm{A}$ & Exclude \\
\hline
\end{tabular}




\begin{tabular}{|c|c|c|c|c|c|c|c|c|}
\hline No. & Indicator name & $\begin{array}{l}\text { Overall \% } \\
\text { of } \\
\text { Agencies } \\
\text { Reporting }\end{array}$ & $\begin{array}{l}\text { Place of } \\
\text { Collection }\end{array}$ & $\begin{array}{l}\text { Facilitators } \\
\text { to Routine } \\
\text { Collection }\end{array}$ & $\begin{array}{l}\text { Barriers to } \\
\text { Routine } \\
\text { Collection }\end{array}$ & $\begin{array}{l}\text { Necessary } \\
\text { Modifications }\end{array}$ & $\begin{array}{l}\text { Resources } \\
\text { Needed for } \\
\text { Routine } \\
\text { Collection }\end{array}$ & Exclude/Include \\
\hline \multirow[t]{5}{*}{2.2} & \multirow{5}{*}{$\begin{array}{l}\text { Number of } \\
\text { clients } \\
\text { receiving an } \\
\text { abortion } \\
\text { referral }\end{array}$} & \multirow[t]{5}{*}{$30 \%$} & & \multirow[t]{5}{*}{$\mathrm{N} / \mathrm{A}$} & $\begin{array}{l}\text { Legal status } \\
\text { of abortion in } \\
\text { Jordan }\end{array}$ & \multirow[t]{5}{*}{$\mathrm{N} / \mathrm{A}$} & $\begin{array}{l}\text { Training on the } \\
\text { new IAFM } \\
\text { guidelines }\end{array}$ & \multirow[t]{5}{*}{ Exclude } \\
\hline & & & & & $\begin{array}{l}\text { Policy and } \\
\text { legislative } \\
\text { changes } \\
\text { needed }\end{array}$ & & $\begin{array}{l}\text { Integration into } \\
\text { HIS/existing } \\
\text { data collection } \\
\text { systems }\end{array}$ & \\
\hline & & & & & \multirow{3}{*}{$\begin{array}{l}\text { Insufficient } \\
\text { security and } \\
\text { privacy } \\
\text { measures set } \\
\text { in place }\end{array}$} & & VCAT sessions & \\
\hline & & & & & & & $\begin{array}{l}\text { Resources and } \\
\text { training } \\
\text { regarding } \\
\text { security \& data } \\
\text { privacy }\end{array}$ & \\
\hline & & & & & & & $\begin{array}{l}\text { Service } \\
\text { mapping } \\
\text { exercise at the } \\
\text { health and/or } \\
\text { humanitarian } \\
\text { sector level to } \\
\text { identify service } \\
\text { provision of } \\
\text { abortions }\end{array}$ & \\
\hline \multirow[t]{5}{*}{2.3} & \multirow{5}{*}{$\begin{array}{l}\text { Number of } \\
\text { clients } \\
\text { receiving an } \\
\text { induced } \\
\text { abortion }\end{array}$} & \multirow[t]{5}{*}{$10 \%$} & & \multirow[t]{5}{*}{$\mathrm{N} / \mathrm{A}$} & $\begin{array}{l}\text { Legal status } \\
\text { of abortion in } \\
\text { Jordan }\end{array}$ & \multirow[t]{5}{*}{$\mathrm{N} / \mathrm{A}$} & $\begin{array}{l}\text { Training on the } \\
\text { new IAFM } \\
\text { guidelines }\end{array}$ & \multirow[t]{5}{*}{ Exclude } \\
\hline & & & & & $\begin{array}{l}\text { Policy and } \\
\text { legislative } \\
\text { changes } \\
\text { needed }\end{array}$ & & $\begin{array}{l}\text { Integration into } \\
\text { HIS/existing } \\
\text { data collection } \\
\text { systems }\end{array}$ & \\
\hline & & & & & \multirow{3}{*}{$\begin{array}{l}\text { Insufficient } \\
\text { security and } \\
\text { privacy } \\
\text { measures set } \\
\text { in place }\end{array}$} & & VCAT sessions & \\
\hline & & & & & & & $\begin{array}{l}\text { Resources and } \\
\text { training } \\
\text { regarding } \\
\text { security \& data } \\
\text { privacy }\end{array}$ & \\
\hline & & & & & & & $\begin{array}{l}\text { Service } \\
\text { mapping } \\
\text { exercise at the } \\
\text { health and/or } \\
\text { humanitarian } \\
\text { sector level to } \\
\text { identify service } \\
\text { provision of } \\
\text { abortions }\end{array}$ & \\
\hline
\end{tabular}




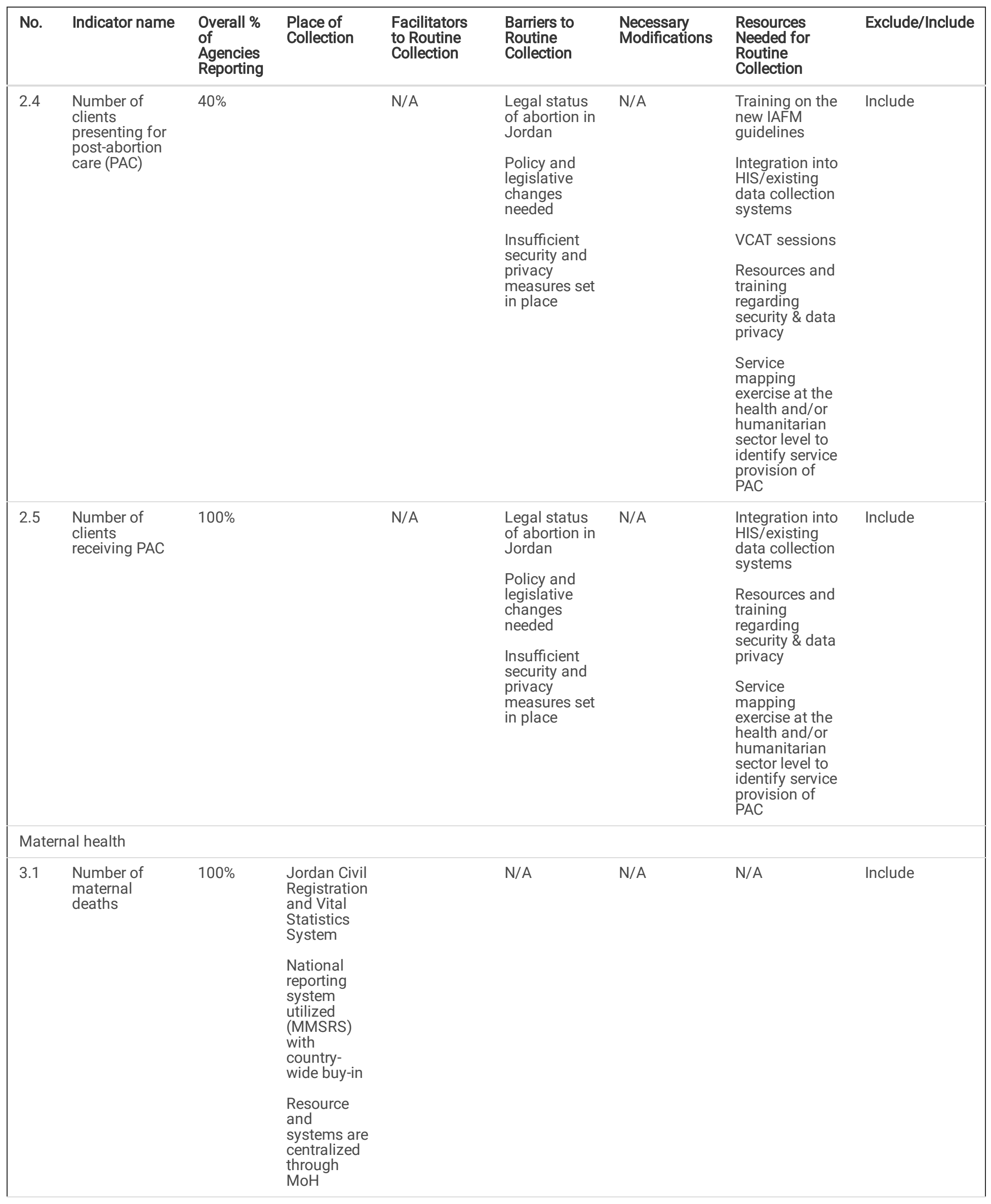




\begin{tabular}{|c|c|c|c|c|c|c|c|c|}
\hline No. & Indicator name & $\begin{array}{l}\text { Overall \% } \\
\text { of } \\
\text { Agencies } \\
\text { Reporting }\end{array}$ & $\begin{array}{l}\text { Place of } \\
\text { Collection }\end{array}$ & $\begin{array}{l}\text { Facilitators } \\
\text { to Routine } \\
\text { Collection }\end{array}$ & $\begin{array}{l}\text { Barriers to } \\
\text { Routine } \\
\text { Collection }\end{array}$ & $\begin{array}{l}\text { Necessary } \\
\text { Modifications }\end{array}$ & $\begin{array}{l}\text { Resources } \\
\text { Needed for } \\
\text { Routine } \\
\text { Collection }\end{array}$ & Exclude/Include \\
\hline 3.2 & $\begin{array}{l}\text { Number of } \\
\text { maternal } \\
\text { deaths, } \\
\text { disaggregated }\end{array}$ & $100 \%$ & & $\begin{array}{l}\text { Jordan Civil } \\
\text { Registration } \\
\text { and Vital } \\
\text { Statistics } \\
\text { System } \\
\text { National } \\
\text { reporting } \\
\text { system } \\
\text { utilized } \\
\text { (MMSRS) } \\
\text { with country- } \\
\text { wide buy-in } \\
\text { Resource } \\
\text { and systems } \\
\text { are } \\
\text { centralized } \\
\text { through MoH }\end{array}$ & $\mathrm{N} / \mathrm{A}$ & $\begin{array}{l}\text { Should } \\
\text { include } 15 \\
\text { and under } \\
\text { category }\end{array}$ & $\mathrm{N} / \mathrm{A}$ & Include \\
\hline 3.3 & $\begin{array}{l}\text { Percentage of } \\
\text { maternal death } \\
\text { reviews }\end{array}$ & $100 \%$ & $\begin{array}{l}\text { Secondary } \\
\text { and tertiary } \\
\text { facilities } \\
\text { only }\end{array}$ & $\begin{array}{l}\text { Jordan Civil } \\
\text { Registration } \\
\text { and Vital } \\
\text { Statistics } \\
\text { System } \\
\text { National } \\
\text { reporting } \\
\text { system } \\
\text { utilized } \\
\text { (MMSRS) } \\
\text { with country- } \\
\text { wide buy-in } \\
\text { Resource } \\
\text { and systems } \\
\text { are } \\
\text { centralized } \\
\text { through MoH }\end{array}$ & $\begin{array}{l}\text { Applicable in } \\
\text { secondary } \\
\text { and tertiary } \\
\text { facilities only }\end{array}$ & $\mathrm{N} / \mathrm{A}$ & $\mathrm{N} / \mathrm{A}$ & Include \\
\hline 3.4 & $\begin{array}{l}\text { Number of } \\
\text { clients } \\
\text { receiving } \\
\text { antenatal care } \\
\text { (ANC) }\end{array}$ & $60 \%$ & & $\mathrm{~N} / \mathrm{A}$ & $\begin{array}{l}\text { Insufficient } \\
\text { security and } \\
\text { privacy } \\
\text { measures set } \\
\text { in place }\end{array}$ & $\mathrm{N} / \mathrm{A}$ & $\begin{array}{l}\text { Resources and } \\
\text { training } \\
\text { regarding } \\
\text { security \& data } \\
\text { privacy }\end{array}$ & Include \\
\hline 3.5 & $\begin{array}{l}\text { Number of } \\
\text { deliveries }\end{array}$ & $70 \%$ & & $\begin{array}{l}\text { Jordan Civil } \\
\text { Registration } \\
\text { and Vital } \\
\text { Statistics } \\
\text { System }\end{array}$ & $\begin{array}{l}\text { Birth registry } \\
\text { not } \\
\text { centralized in } \\
\text { facilities } \\
\text { Policy and } \\
\text { legislative } \\
\text { changes } \\
\text { surrounding } \\
\text { birth registry } \\
\text { and reporting } \\
\text { requirements } \\
\text { of stillbirths } \\
\text { Insufficient } \\
\text { security and } \\
\text { privacy } \\
\text { measures set } \\
\text { in place }\end{array}$ & $\mathrm{N} / \mathrm{A}$ & $\begin{array}{l}\text { Training on } \\
\text { how to report } \\
\text { stillbirths } \\
\text { Centralizing } \\
\text { birth registry in } \\
\text { secondary and } \\
\text { tertiary } \\
\text { facilities } \\
\text { Integration into } \\
\text { HIS/existing } \\
\text { data collection } \\
\text { systems } \\
\text { Resources and } \\
\text { training } \\
\text { regarding } \\
\text { security \& data } \\
\text { privacy }\end{array}$ & Include \\
\hline
\end{tabular}




\begin{tabular}{|c|c|c|c|c|c|c|c|c|}
\hline No. & Indicator name & $\begin{array}{l}\text { Overall \% } \\
\text { of } \\
\text { Agencies } \\
\text { Reporting }\end{array}$ & $\begin{array}{l}\text { Place of } \\
\text { Collection }\end{array}$ & $\begin{array}{l}\text { Facilitators } \\
\text { to Routine } \\
\text { Collection }\end{array}$ & $\begin{array}{l}\text { Barriers to } \\
\text { Routine } \\
\text { Collection }\end{array}$ & $\begin{array}{l}\text { Necessary } \\
\text { Modifications }\end{array}$ & $\begin{array}{l}\text { Resources } \\
\text { Needed for } \\
\text { Routine } \\
\text { Collection }\end{array}$ & Exclude/Include \\
\hline 3.6 & $\begin{array}{l}\text { Number of } \\
\text { deliveries, } \\
\text { disaggregated }\end{array}$ & $60 \%$ & & $\begin{array}{l}\text { Jordan Civil } \\
\text { Registration } \\
\text { and Vital } \\
\text { Statistics } \\
\text { System }\end{array}$ & $\begin{array}{l}\text { Birth registry } \\
\text { not } \\
\text { centralized in } \\
\text { facilities } \\
\text { Policy and } \\
\text { legislative } \\
\text { changes } \\
\text { surrounding } \\
\text { birth registry } \\
\text { and reporting } \\
\text { requirements } \\
\text { of stillbirths } \\
\text { Insufficient } \\
\text { security and } \\
\text { privacy } \\
\text { measures set } \\
\text { in place }\end{array}$ & $\mathrm{N} / \mathrm{A}$ & $\begin{array}{l}\text { Training on } \\
\text { how to report } \\
\text { stillbirths } \\
\text { Centralizing } \\
\text { birth registry in } \\
\text { secondary and } \\
\text { tertiary } \\
\text { facilities } \\
\text { Integration into } \\
\text { HIS/existing } \\
\text { data collection } \\
\text { systems } \\
\text { Resources and } \\
\text { training } \\
\text { regarding } \\
\text { security \& data } \\
\text { privacy }\end{array}$ & Include \\
\hline 3.7 & $\begin{array}{l}\text { Number of } \\
\text { clients } \\
\text { receiving post- } \\
\text { natal care } \\
\text { (PNC) }\end{array}$ & $50 \%$ & $\begin{array}{l}\text { Secondary } \\
\text { and tertiary } \\
\text { facilities } \\
\text { only }\end{array}$ & $\mathrm{N} / \mathrm{A}$ & $\begin{array}{l}\text { Applicable in } \\
\text { secondary } \\
\text { and tertiary } \\
\text { facilities only } \\
\text { Insufficient } \\
\text { security and } \\
\text { privacy } \\
\text { measures set } \\
\text { in place }\end{array}$ & $\mathrm{N} / \mathrm{A}$ & $\begin{array}{l}\text { Resources and } \\
\text { training } \\
\text { regarding } \\
\text { security \& data } \\
\text { privacy }\end{array}$ & Include \\
\hline 3.8 & $\begin{array}{l}\text { Number of } \\
\text { caesarean } \\
\text { section } \\
\text { deliveries }\end{array}$ & $60 \%$ & $\begin{array}{l}\text { Tertiary } \\
\text { facilities } \\
\text { only }\end{array}$ & N/A & $\begin{array}{l}\text { Applicable in } \\
\text { tertiary } \\
\text { facilities only } \\
\text { Insufficient } \\
\text { security and } \\
\text { privacy } \\
\text { measures set } \\
\text { in place }\end{array}$ & $\mathrm{N} / \mathrm{A}$ & $\begin{array}{l}\text { Resources and } \\
\text { training } \\
\text { regarding } \\
\text { security \& data } \\
\text { privacy }\end{array}$ & Include \\
\hline 3.9 & $\begin{array}{l}\text { Availability of } \\
\text { PAC }\end{array}$ & $0 \%$ & $\mathrm{~N} / \mathrm{A}$ & $\mathrm{N} / \mathrm{A}$ & $\mathrm{N} / \mathrm{A}$ & $\mathrm{N} / \mathrm{A}$ & $\begin{array}{l}\text { Service } \\
\text { mapping } \\
\text { exercise at the } \\
\text { health and/or } \\
\text { humanitarian } \\
\text { sector level to } \\
\text { identify service } \\
\text { provision of } \\
\text { PAC }\end{array}$ & Exclude \\
\hline 3.10 & $\begin{array}{l}\text { Availability of } \\
\text { basic } \\
\text { emergency } \\
\text { obstetric care } \\
\text { (BEmOC) }\end{array}$ & $0 \%$ & $\mathrm{~N} / \mathrm{A}$ & $\mathrm{N} / \mathrm{A}$ & N/A & $\mathrm{N} / \mathrm{A}$ & $\begin{array}{l}\text { Service } \\
\text { mapping } \\
\text { exercise at the } \\
\text { health and/or } \\
\text { humanitarian } \\
\text { sector level to } \\
\text { identify service } \\
\text { provision of } \\
\text { BEmOC }\end{array}$ & Exclude \\
\hline 3.11 & $\begin{array}{l}\text { Availability of } \\
\text { comprehensive } \\
\text { emergency } \\
\text { obstetric care } \\
\text { (CEmOC) }\end{array}$ & $0 \%$ & $\mathrm{~N} / \mathrm{A}$ & $\mathrm{N} / \mathrm{A}$ & $\mathrm{N} / \mathrm{A}$ & $\mathrm{N} / \mathrm{A}$ & $\begin{array}{l}\text { Service } \\
\text { mapping } \\
\text { exercise at the } \\
\text { health and/or } \\
\text { humanitarian } \\
\text { sector level to } \\
\text { identify service } \\
\text { provision of } \\
\text { CEmOC }\end{array}$ & Exclude \\
\hline
\end{tabular}




\begin{tabular}{|c|c|c|c|c|c|c|c|c|}
\hline No. & Indicator name & $\begin{array}{l}\text { Overall \% } \\
\text { of } \\
\text { Agencies } \\
\text { Reporting }\end{array}$ & $\begin{array}{l}\text { Place of } \\
\text { Collection }\end{array}$ & $\begin{array}{l}\text { Facilitators } \\
\text { to Routine } \\
\text { Collection }\end{array}$ & $\begin{array}{l}\text { Barriers to } \\
\text { Routine } \\
\text { Collection }\end{array}$ & $\begin{array}{l}\text { Necessary } \\
\text { Modifications }\end{array}$ & $\begin{array}{l}\text { Resources } \\
\text { Needed for } \\
\text { Routine } \\
\text { Collection }\end{array}$ & Exclude/Include \\
\hline 3.12 & $\begin{array}{l}\text { Availability of } \\
\text { skilled } \\
\text { personnel }\end{array}$ & $0 \%$ & N/A & $\mathrm{N} / \mathrm{A}$ & $\begin{array}{l}\text { Irrelevant to } \\
\text { context as } \\
\text { high quality } \\
\text { medical care } \\
\text { is readily } \\
\text { available }\end{array}$ & $\mathrm{N} / \mathrm{A}$ & $\mathrm{N} / \mathrm{A}$ & Exclude \\
\hline 3.13 & $\begin{array}{l}\text { Number of } \\
\text { antenatal care } \\
\text { clients with } \\
\text { tetanus } \\
\text { vaccination }\end{array}$ & $70 \%$ & & $\mathrm{~N} / \mathrm{A}$ & $\begin{array}{l}\text { Low burden } \\
\text { of disease, } \\
\text { service not } \\
\text { routinely } \\
\text { provided }\end{array}$ & $\mathrm{N} / \mathrm{A}$ & $\mathrm{N} / \mathrm{A}$ & Exclude \\
\hline 3.14 & $\begin{array}{l}\text { Number of } \\
\text { ANC clients } \\
\text { receiving } \\
\text { preventive } \\
\text { therapy for } \\
\text { malaria }\end{array}$ & $0 \%$ & $\mathrm{~N} / \mathrm{A}$ & $\mathrm{N} / \mathrm{A}$ & $\begin{array}{l}\text { Low burden } \\
\text { of disease, } \\
\text { service not } \\
\text { routinely } \\
\text { provided }\end{array}$ & $\mathrm{N} / \mathrm{A}$ & $\mathrm{N} / \mathrm{A}$ & Exclude \\
\hline 3.15 & $\begin{array}{l}\text { Number of } \\
\text { ANC clients } \\
\text { receiving } \\
\text { syphilis } \\
\text { screening }\end{array}$ & $0 \%$ & $\mathrm{~N} / \mathrm{A}$ & $\mathrm{N} / \mathrm{A}$ & $\begin{array}{l}\text { Low burden } \\
\text { of disease, } \\
\text { service not } \\
\text { routinely } \\
\text { provided }\end{array}$ & $\mathrm{N} / \mathrm{A}$ & $\mathrm{N} / \mathrm{A}$ & Exclude \\
\hline 3.16 & $\begin{array}{l}\text { Number of } \\
\text { ANC clients } \\
\text { receiving } \\
\text { urinary tract } \\
\text { infection } \\
\text { screening or } \\
\text { treatment }\end{array}$ & $0 \%$ & $\mathrm{~N} / \mathrm{A}$ & $\mathrm{N} / \mathrm{A}$ & $\begin{array}{l}\text { Low burden } \\
\text { of disease, } \\
\text { information } \\
\text { not } \\
\text { actionable }\end{array}$ & $\mathrm{N} / \mathrm{A}$ & $\mathrm{N} / \mathrm{A}$ & Exclude \\
\hline 3.17 & $\begin{array}{l}\text { Number of } \\
\text { clients with } \\
\text { identified } \\
\text { maternal } \\
\text { morbidities } \\
\text { during post- } \\
\text { natal care } \\
\text { (PNC) }\end{array}$ & $60 \%$ & & $\mathrm{~N} / \mathrm{A}$ & $\begin{array}{l}\text { Insufficient } \\
\text { security and } \\
\text { privacy } \\
\text { measures set } \\
\text { in place }\end{array}$ & $\begin{array}{l}\text { Specify } \\
\text { morbidity } \\
\text { types }\end{array}$ & $\begin{array}{l}\text { Resources } \\
\text { needed to } \\
\text { specify } \\
\text { morbidity types } \\
\text { (i.e.: training of } \\
\text { staff and } \\
\text { creating and } \\
\text { distributing } \\
\text { manuals on } \\
\text { types of } \\
\text { maternal } \\
\text { morbidities } \\
\text { during PNC) } \\
\text { Resources and } \\
\text { training } \\
\text { regarding } \\
\text { security \& data } \\
\text { privacy }\end{array}$ & Include \\
\hline
\end{tabular}




\begin{tabular}{|c|c|c|c|c|c|c|c|c|}
\hline No. & Indicator name & $\begin{array}{l}\text { Overall \% } \\
\text { of } \\
\text { Agencies } \\
\text { Reporting }\end{array}$ & $\begin{array}{l}\text { Place of } \\
\text { Collection }\end{array}$ & $\begin{array}{l}\text { Facilitators } \\
\text { to Routine } \\
\text { Collection }\end{array}$ & $\begin{array}{l}\text { Barriers to } \\
\text { Routine } \\
\text { Collection }\end{array}$ & $\begin{array}{l}\text { Necessary } \\
\text { Modifications }\end{array}$ & $\begin{array}{l}\text { Resources } \\
\text { Needed for } \\
\text { Routine } \\
\text { Collection }\end{array}$ & Exclude/Include \\
\hline 4.1 & $\begin{array}{l}\text { Number of } \\
\text { neonatal } \\
\text { deaths }\end{array}$ & $60 \%$ & & $\begin{array}{l}\text { Jordan Civil } \\
\text { Registration } \\
\text { and Vital } \\
\text { Statistics } \\
\text { System }\end{array}$ & $\begin{array}{l}\text { No national } \\
\text { system to } \\
\text { review } \\
\text { newborn } \\
\text { death } \\
\text { Insufficient } \\
\text { security and } \\
\text { privacy } \\
\text { measures set } \\
\text { in place }\end{array}$ & $\mathrm{N} / \mathrm{A}$ & $\begin{array}{l}\text { Resources } \\
\text { needed to } \\
\text { establish } \\
\text { national } \\
\text { systems to } \\
\text { capture } \\
\text { newborn death } \\
\text { and review } \\
\text { these cases for } \\
\text { cause of death } \\
\text { (development } \\
\text { and } \\
\text { implementation } \\
\text { of a perinatal } \\
\text { surveillance } \\
\text { system) } \\
\text { Training of } \\
\text { primary care } \\
\text { providers on } \\
\text { how to report } \\
\text { on neonatal } \\
\text { death } \\
\text { Resources and } \\
\text { training } \\
\text { regarding } \\
\text { security \& data } \\
\text { privacy }\end{array}$ & Include \\
\hline 4.2 & $\begin{array}{l}\text { Number of } \\
\text { stillbirths }\end{array}$ & $60 \%$ & & $\begin{array}{l}\text { Jordan Civil } \\
\text { Registration } \\
\text { and Vital } \\
\text { Statistics } \\
\text { System }\end{array}$ & $\mathrm{N} / \mathrm{A}$ & $\mathrm{N} / \mathrm{A}$ & $\begin{array}{l}\text { Training on } \\
\text { how to report } \\
\text { on stillbirths } \\
\text { Integration into } \\
\text { HIS/existing } \\
\text { data collection } \\
\text { systems }\end{array}$ & Include \\
\hline 4.3 & $\begin{array}{l}\text { Number of } \\
\text { babies born } \\
\text { low birth } \\
\text { weight }\end{array}$ & $60 \%$ & & $\mathrm{~N} / \mathrm{A}$ & $\mathrm{N} / \mathrm{A}$ & $\begin{array}{l}\text { Specification } \\
\text { of the weight } \\
(\text { e.g.: <2500) }\end{array}$ & $\mathrm{N} / \mathrm{A}$ & Include \\
\hline 4.4 & $\begin{array}{l}\text { Number of } \\
\text { small and sick } \\
\text { newborns } \\
\text { receiving care }\end{array}$ & $60 \%$ & & $\mathrm{~N} / \mathrm{A}$ & $\mathrm{N} / \mathrm{A}$ & $\mathrm{N} / \mathrm{A}$ & $\mathrm{N} / \mathrm{A}$ & Include \\
\hline 4.5 & $\begin{array}{l}\text { Number of } \\
\text { newborns } \\
\text { receiving post- } \\
\text { natal care }\end{array}$ & $60 \%$ & & $\mathrm{~N} / \mathrm{A}$ & $\mathrm{N} / \mathrm{A}$ & $\mathrm{N} / \mathrm{A}$ & $\mathrm{N} / \mathrm{A}$ & Include \\
\hline 4.6 & $\begin{array}{l}\text { Availability of } \\
\text { KMC }\end{array}$ & $0 \%$ & $\mathrm{~N} / \mathrm{A}$ & $\mathrm{N} / \mathrm{A}$ & $\begin{array}{l}\text { Service not } \\
\text { routinely } \\
\text { provided; } \\
\text { information } \\
\text { not } \\
\text { actionable }\end{array}$ & $\mathrm{N} / \mathrm{A}$ & $\mathrm{N} / \mathrm{A}$ & Exclude \\
\hline 4.7 & $\begin{array}{l}\text { Availability of } \\
\text { neonatal } \\
\text { resuscitation }\end{array}$ & $0 \%$ & $\mathrm{~N} / \mathrm{A}$ & $\mathrm{N} / \mathrm{A}$ & $\begin{array}{l}\text { Irrelevant to } \\
\text { context as } \\
\text { high quality } \\
\text { medical care } \\
\text { is readily } \\
\text { available } \\
\text { In-patient } \\
\text { health care } \\
\text { system }\end{array}$ & $\mathrm{N} / \mathrm{A}$ & $\begin{array}{l}\text { Service } \\
\text { mapping } \\
\text { exercise at the } \\
\text { health and/or } \\
\text { humanitarian } \\
\text { sector level to } \\
\text { identify service } \\
\text { provision of } \\
\text { neonatal } \\
\text { resuscitation }\end{array}$ & Exclude \\
\hline
\end{tabular}




\begin{tabular}{|c|c|c|c|c|c|c|c|c|}
\hline No. & Indicator name & $\begin{array}{l}\text { Overall \% } \\
\text { of } \\
\text { Agencies } \\
\text { Reporting }\end{array}$ & $\begin{array}{l}\text { Place of } \\
\text { Collection }\end{array}$ & $\begin{array}{l}\text { Facilitators } \\
\text { to Routine } \\
\text { Collection }\end{array}$ & $\begin{array}{l}\text { Barriers to } \\
\text { Routine } \\
\text { Collection }\end{array}$ & $\begin{array}{l}\text { Necessary } \\
\text { Modifications }\end{array}$ & $\begin{array}{l}\text { Resources } \\
\text { Needed for } \\
\text { Routine } \\
\text { Collection }\end{array}$ & Exclude/Include \\
\hline \multirow[t]{2}{*}{4.8} & $\begin{array}{l}\text { Number of } \\
\text { neonatal } \\
\text { deaths, } \\
\text { disaggregated }\end{array}$ & $60 \%$ & & $\begin{array}{l}\text { Jordan Civil } \\
\text { Registration } \\
\text { and Vital } \\
\text { Statistics } \\
\text { System }\end{array}$ & $\begin{array}{l}\text { No national } \\
\text { system to } \\
\text { review } \\
\text { newborn } \\
\text { death }\end{array}$ & N/A & $\begin{array}{l}\text { Resources } \\
\text { needed to } \\
\text { establish } \\
\text { national } \\
\text { systems to } \\
\text { capture } \\
\text { newborn death } \\
\text { and review } \\
\text { these cases for } \\
\text { cause of death } \\
\text { (development } \\
\text { and } \\
\text { implementation } \\
\text { of a perinatal } \\
\text { surveillance } \\
\text { system) }\end{array}$ & Include \\
\hline & & & & & & & $\begin{array}{l}\text { Training of } \\
\text { primary care } \\
\text { providers }\end{array}$ & \\
\hline \multirow[t]{2}{*}{4.9} & $\begin{array}{l}\text { Percentage of } \\
\text { perinatal death } \\
\text { reviews }\end{array}$ & $10 \%$ & & N/A & $\begin{array}{l}\text { No national } \\
\text { system to } \\
\text { review } \\
\text { newborn } \\
\text { death }\end{array}$ & N/A & $\begin{array}{l}\text { Resources } \\
\text { needed to } \\
\text { establish } \\
\text { national } \\
\text { systems to } \\
\text { capture } \\
\text { newborn death } \\
\text { and review } \\
\text { these cases for } \\
\text { cause of death } \\
\text { (development } \\
\text { and } \\
\text { implementation } \\
\text { of a perinatal } \\
\text { surveillance } \\
\text { system) }\end{array}$ & Include \\
\hline & & & & & & & $\begin{array}{l}\text { Training of } \\
\text { primary care } \\
\text { providers }\end{array}$ & \\
\hline 4.10 & $\begin{array}{l}\text { Number of } \\
\text { newborns } \\
\text { receiving } \\
\text { Hepatitis B } \\
\text { vaccine }\end{array}$ & $0 \%$ & N/A & N/A & & N/A & $\begin{array}{l}\text { Integration into } \\
\text { HIS/existing } \\
\text { data collection } \\
\text { systems }\end{array}$ & Include \\
\hline 4.11 & $\begin{array}{l}\text { Number of } \\
\text { newborns } \\
\text { initiating } \\
\text { breastfeeding } \\
\text { early }\end{array}$ & $0 \%$ & N/A & N/A & $\begin{array}{l}\text { Information } \\
\text { not } \\
\text { actionable }\end{array}$ & N/A & N/A & Exclude \\
\hline 4.12 & $\begin{array}{l}\text { Number of } \\
\text { infants } \\
\text { weighed at } \\
\text { birth }\end{array}$ & $0 \%$ & N/A & N/A & $\mathrm{N} / \mathrm{A}$ & N/A & $\begin{array}{l}\text { Integration into } \\
\text { HIS/existing } \\
\text { data collection } \\
\text { systems }\end{array}$ & Include \\
\hline 4.13 & $\begin{array}{l}\text { Number of } \\
\text { babies } \\
\text { registered }\end{array}$ & $0 \%$ & N/A & $\begin{array}{l}\text { Jordan Civil } \\
\text { Registration } \\
\text { and Vital } \\
\text { Statistics } \\
\text { System }\end{array}$ & $\begin{array}{l}\text { Civil registry } \\
\text { not } \\
\text { centralized in } \\
\text { facilities }\end{array}$ & & $\begin{array}{l}\text { Resources } \\
\text { needed to } \\
\text { integrate civil } \\
\text { registry in } \\
\text { facilities }\end{array}$ & Include \\
\hline 4.14 & $\begin{array}{l}\text { Number of } \\
\text { newborns } \\
\text { receiving } \\
\text { treatment for } \\
\text { possible } \\
\text { severe } \\
\text { bacterial } \\
\text { infection } \\
\text { (PSBI) }\end{array}$ & $0 \%$ & N/A & N/A & N/A & N/A & $\begin{array}{l}\text { Integration into } \\
\text { HIS/existing } \\
\text { data collection } \\
\text { systems }\end{array}$ & Include \\
\hline
\end{tabular}




\begin{tabular}{|c|c|c|c|c|c|c|c|c|}
\hline No. & Indicator name & $\begin{array}{l}\text { Overall \% } \\
\text { of } \\
\text { Agencies } \\
\text { Reporting }\end{array}$ & $\begin{array}{l}\text { Place of } \\
\text { Collection }\end{array}$ & $\begin{array}{l}\text { Facilitators } \\
\text { to Routine } \\
\text { Collection }\end{array}$ & $\begin{array}{l}\text { Barriers to } \\
\text { Routine } \\
\text { Collection }\end{array}$ & $\begin{array}{l}\text { Necessary } \\
\text { Modifications }\end{array}$ & $\begin{array}{l}\text { Resources } \\
\text { Needed for } \\
\text { Routine } \\
\text { Collection }\end{array}$ & Exclude/Include \\
\hline 4.15 & $\begin{array}{l}\text { Number of } \\
\text { newborns } \\
\text { admitted }\end{array}$ & $60 \%$ & $\begin{array}{l}\text { Secondary } \\
\text { and tertiary } \\
\text { facilities } \\
\text { only }\end{array}$ & N/A & $\begin{array}{l}\text { Applicable in } \\
\text { secondary } \\
\text { and tertiary } \\
\text { facilities only }\end{array}$ & $\mathrm{N} / \mathrm{A}$ & $\mathrm{N} / \mathrm{A}$ & Include \\
\hline 4.16 & $\begin{array}{l}\text { Number of } \\
\text { newborns with } \\
\text { morbidities } \\
\text { identified } \\
\text { during PNC }\end{array}$ & $0 \%$ & $\mathrm{~N} / \mathrm{A}$ & N/A & $\mathrm{N} / \mathrm{A}$ & $\begin{array}{l}\text { Specify } \\
\text { morbidity } \\
\text { types }\end{array}$ & $\begin{array}{l}\text { Resources } \\
\text { needed to } \\
\text { specify } \\
\text { morbidity types }\end{array}$ & Include \\
\hline \multicolumn{9}{|c|}{ Child health } \\
\hline 5.1 & $\begin{array}{l}\text { Number of } \\
\text { deaths of } \\
\text { children under } \\
5\end{array}$ & $0 \%$ & $\mathrm{~N} / \mathrm{A}$ & $\begin{array}{l}\text { Jordan Civil } \\
\text { Registration } \\
\text { and Vital } \\
\text { Statistics } \\
\text { System }\end{array}$ & $\mathrm{N} / \mathrm{A}$ & $\mathrm{N} / \mathrm{A}$ & $\mathrm{N} / \mathrm{A}$ & Include \\
\hline 5.2 & $\begin{array}{l}\text { Under } 5 \\
\text { mortality rate }\end{array}$ & $0 \%$ & N/A & N/A & $\begin{array}{l}\text { Population } \\
\text { level } \\
\text { indicator } \\
\text { with } \\
\text { impractical } \\
\text { denominator }\end{array}$ & $\begin{array}{l}\text { Convert to } \\
\text { facility-based } \\
\text { indicator for } \\
\text { routine } \\
\text { collection }\end{array}$ & $\mathrm{N} / \mathrm{A}$ & Exclude \\
\hline 5.3 & $\begin{array}{l}\text { Percentage of } \\
\text { children under } \\
5 \text { with } \\
\text { suspected } \\
\text { pneumonia } \\
\text { taken to } \\
\text { appropriate } \\
\text { health facility }\end{array}$ & $0 \%$ & $\mathrm{~N} / \mathrm{A}$ & N/A & $\begin{array}{l}\text { Population } \\
\text { level } \\
\text { indicator } \\
\text { with } \\
\text { impractical } \\
\text { denominator }\end{array}$ & $\begin{array}{l}\text { Convert to } \\
\text { facility-based } \\
\text { indicator for } \\
\text { routine } \\
\text { collection }\end{array}$ & $\mathrm{N} / \mathrm{A}$ & Exclude \\
\hline 5.4 & $\begin{array}{l}\text { Coverage of } \\
\text { diarrhea } \\
\text { treatment }\end{array}$ & $0 \%$ & $\mathrm{~N} / \mathrm{A}$ & N/A & N/A & $\mathrm{N} / \mathrm{A}$ & N/A & Include \\
\hline 5.5 & $\begin{array}{l}\text { Percentage of } \\
\text { children under } \\
5 \text { who are } \\
\text { wasted }\end{array}$ & $0 \%$ & N/A & N/A & $\begin{array}{l}\text { Low burden } \\
\text { of disease } \\
\text { Population- } \\
\text { level } \\
\text { indicator } \\
\text { with } \\
\text { impractical } \\
\text { denominator }\end{array}$ & $\begin{array}{l}\text { Convert to } \\
\text { facility-based } \\
\text { indicator for } \\
\text { routine } \\
\text { collection }\end{array}$ & $\mathrm{N} / \mathrm{A}$ & Exclude \\
\hline 5.6 & $\begin{array}{l}\text { Percentage of } \\
\text { children under } \\
5 \text { who are } \\
\text { registered }\end{array}$ & $0 \%$ & N/A & $\begin{array}{l}\text { Jordan Civil } \\
\text { Registration } \\
\text { and Vital } \\
\text { Statistics } \\
\text { System }\end{array}$ & $\begin{array}{l}\text { Complicated } \\
\text { by national } \\
\text { registry } \\
\text { system; } \\
\text { system } \\
\text { allows for a } \\
\text { 30-day grace } \\
\text { period for the } \\
\text { male } \\
\text { guardian to } \\
\text { register the } \\
\text { birth of the } \\
\text { child which } \\
\text { can result in } \\
\text { lack of } \\
\text { registration if } \\
\text { a newborn } \\
\text { death occurs } \\
\text { within } 30 \\
\text { days }\end{array}$ & $\begin{array}{l}\text { Convert to } \\
\text { facility-based } \\
\text { indicator for } \\
\text { routine } \\
\text { collection }\end{array}$ & $\mathrm{N} / \mathrm{A}$ & Include \\
\hline
\end{tabular}




\begin{tabular}{|c|c|c|c|c|c|c|c|c|}
\hline No. & Indicator name & $\begin{array}{l}\text { Overall \% } \\
\text { of } \\
\text { Agencies } \\
\text { Reporting }\end{array}$ & $\begin{array}{l}\text { Place of } \\
\text { Collection }\end{array}$ & $\begin{array}{l}\text { Facilitators } \\
\text { to Routine } \\
\text { Collection }\end{array}$ & $\begin{array}{l}\text { Barriers to } \\
\text { Routine } \\
\text { Collection }\end{array}$ & $\begin{array}{l}\text { Necessary } \\
\text { Modifications }\end{array}$ & $\begin{array}{l}\text { Resources } \\
\text { Needed for } \\
\text { Routine } \\
\text { Collection }\end{array}$ & Exclude/Include \\
\hline 5.7 & $\begin{array}{l}\text { Number of } \\
\text { children } \\
\text { presenting } \\
\text { with fever } \\
\text { tested for } \\
\text { malaria in } \\
\text { endemic } \\
\text { settings }\end{array}$ & $0 \%$ & N/A & $\mathrm{N} / \mathrm{A}$ & $\begin{array}{l}\text { Low burden } \\
\text { of disease, } \\
\text { service not } \\
\text { routinely } \\
\text { provided } \\
\text { Specific } \\
\text { infectious } \\
\text { disease } \\
\text { reporting } \\
\text { requirements } \\
\text { and } \\
\text { management } \\
\text { protocols for } \\
\text { individual } \\
\text { cases }\end{array}$ & $\mathrm{N} / \mathrm{A}$ & $\mathrm{N} / \mathrm{A}$ & Exclude \\
\hline 5.8 & $\begin{array}{l}\text { Number of } \\
\text { confirmed } \\
\text { cases of } \\
\text { malaria in } \\
\text { endemic } \\
\text { settings }\end{array}$ & $0 \%$ & $\mathrm{~N} / \mathrm{A}$ & $\mathrm{N} / \mathrm{A}$ & $\begin{array}{l}\text { Low burden } \\
\text { of disease, } \\
\text { service not } \\
\text { routinely } \\
\text { provided } \\
\text { Specific } \\
\text { infectious } \\
\text { disease } \\
\text { reporting } \\
\text { requirements } \\
\text { and } \\
\text { management } \\
\text { protocols for } \\
\text { individual } \\
\text { cases }\end{array}$ & $\mathrm{N} / \mathrm{A}$ & $\mathrm{N} / \mathrm{A}$ & Exclude \\
\hline 5.9 & $\begin{array}{l}\text { Percentage of } \\
\text { confirmed } \\
\text { malaria cases } \\
\text { treated }\end{array}$ & $0 \%$ & $\mathrm{~N} / \mathrm{A}$ & $\mathrm{N} / \mathrm{A}$ & $\begin{array}{l}\text { Low burden } \\
\text { of disease, } \\
\text { service not } \\
\text { routinely } \\
\text { provided } \\
\text { Specific } \\
\text { infectious } \\
\text { disease } \\
\text { reporting } \\
\text { requirements } \\
\text { and } \\
\text { management } \\
\text { protocols for } \\
\text { individual } \\
\text { cases }\end{array}$ & $\mathrm{N} / \mathrm{A}$ & $\mathrm{N} / \mathrm{A}$ & Exclude \\
\hline 5.10 & $\begin{array}{l}\text { Coverage of } \\
\text { DP3 }\end{array}$ & $0 \%$ & $\mathrm{~N} / \mathrm{A}$ & $\mathrm{N} / \mathrm{A}$ & $\begin{array}{l}\text { Population- } \\
\text { level } \\
\text { indicator } \\
\text { with } \\
\text { impractical } \\
\text { denominator }\end{array}$ & $\begin{array}{l}\text { Convert to } \\
\text { facility-based } \\
\text { indicator for } \\
\text { routine } \\
\text { collection }\end{array}$ & $\mathrm{N} / \mathrm{A}$ & Exclude \\
\hline \multicolumn{9}{|c|}{ Adolescent health } \\
\hline 6.1 & $\begin{array}{l}\text { Adolescent } \\
\text { birth rate }\end{array}$ & $0 \%$ & $\mathrm{~N} / \mathrm{A}$ & $\begin{array}{l}\text { National } \\
\text { Reporting } \\
\text { System: } \\
\text { NSSRH } \\
\text { (Higher } \\
\text { Population } \\
\text { Council) }\end{array}$ & $\begin{array}{l}\text { Population- } \\
\text { level } \\
\text { indicator } \\
\text { with } \\
\text { impractical } \\
\text { denominator }\end{array}$ & $\begin{array}{l}\text { Convert to } \\
\text { facility-based } \\
\text { indicator for } \\
\text { routine } \\
\text { collection }\end{array}$ & $\mathrm{N} / \mathrm{A}$ & Exclude \\
\hline
\end{tabular}




\begin{tabular}{|c|c|c|c|c|c|c|c|c|}
\hline No. & Indicator name & $\begin{array}{l}\text { Overall \% } \\
\text { of } \\
\text { Agencies } \\
\text { Reporting }\end{array}$ & $\begin{array}{l}\text { Place of } \\
\text { Collection }\end{array}$ & $\begin{array}{l}\text { Facilitators } \\
\text { to Routine } \\
\text { Collection }\end{array}$ & $\begin{array}{l}\text { Barriers to } \\
\text { Routine } \\
\text { Collection }\end{array}$ & $\begin{array}{l}\text { Necessary } \\
\text { Modifications }\end{array}$ & $\begin{array}{l}\text { Resources } \\
\text { Needed for } \\
\text { Routine } \\
\text { Collection }\end{array}$ & Exclude/Include \\
\hline 6.2 & $\begin{array}{l}\text { Sexual } \\
\text { violence } \\
\text { against } \\
\text { children }\end{array}$ & $0 \%$ & N/A & $\mathrm{N} / \mathrm{A}$ & $\begin{array}{l}\text { Information } \\
\text { not } \\
\text { actionable } \\
\text { Population- } \\
\text { level } \\
\text { indicator } \\
\text { with } \\
\text { impractical } \\
\text { denominator }\end{array}$ & $\begin{array}{l}\text { Convert to } \\
\text { facility-based } \\
\text { indicator for } \\
\text { routine } \\
\text { collection }\end{array}$ & $\mathrm{N} / \mathrm{A}$ & Exclude \\
\hline 6.3 & $\begin{array}{l}\text { Adolescent } \\
\text { mortality rate }\end{array}$ & $0 \%$ & $\mathrm{~N} / \mathrm{A}$ & $\mathrm{N} / \mathrm{A}$ & $\begin{array}{l}\text { Population- } \\
\text { level } \\
\text { indicator } \\
\text { with } \\
\text { impractical } \\
\text { denominator }\end{array}$ & $\begin{array}{l}\text { Convert to } \\
\text { facility-based } \\
\text { indicator for } \\
\text { routine } \\
\text { collection }\end{array}$ & $\mathrm{N} / \mathrm{A}$ & Include \\
\hline 6.4 & $\begin{array}{l}\text { Percentage of } \\
\text { adolescents } \\
\text { living with HIV } \\
\text { who are } \\
\text { currently } \\
\text { receiving } \\
\text { antiretroviral } \\
\text { therapy, } \\
\text { disaggregated }\end{array}$ & $0 \%$ & N/A & $\mathrm{N} / \mathrm{A}$ & $\begin{array}{l}\text { National HIV } \\
\text { reporting } \\
\text { requirements } \\
\text { and } \\
\text { management } \\
\text { protocols for } \\
\text { individual } \\
\text { cases } \\
\text { Population- } \\
\text { level } \\
\text { indicator } \\
\text { with } \\
\text { impractical } \\
\text { denominator }\end{array}$ & $\begin{array}{l}\text { Convert to } \\
\text { facility-based } \\
\text { indicator for } \\
\text { routine } \\
\text { collection }\end{array}$ & N/A & Exclude \\
\hline 6.5 & $\begin{array}{l}\text { Immunization } \\
\text { coverage rate }\end{array}$ & $0 \%$ & $\mathrm{~N} / \mathrm{A}$ & $\mathrm{N} / \mathrm{A}$ & $\begin{array}{l}\text { Population- } \\
\text { level } \\
\text { indicator } \\
\text { with } \\
\text { impractical } \\
\text { denominator }\end{array}$ & $\begin{array}{l}\text { Convert to } \\
\text { facility-based } \\
\text { indicator for } \\
\text { routine } \\
\text { collection }\end{array}$ & $\mathrm{N} / \mathrm{A}$ & Exclude \\
\hline 6.6 & $\begin{array}{l}\text { Suicide rate, } \\
\text { disaggregated }\end{array}$ & $0 \%$ & $\mathrm{~N} / \mathrm{A}$ & $\mathrm{N} / \mathrm{A}$ & $\begin{array}{l}\text { Information } \\
\text { not } \\
\text { actionable } \\
\text { Population- } \\
\text { level } \\
\text { indicator } \\
\text { with } \\
\text { impractical } \\
\text { denominator }\end{array}$ & $\begin{array}{l}\text { Convert to } \\
\text { facility-based } \\
\text { indicator for } \\
\text { routine } \\
\text { collection }\end{array}$ & $\mathrm{N} / \mathrm{A}$ & Exclude \\
\hline \multicolumn{9}{|c|}{ Sexual and gender-based violence } \\
\hline 7.1 & $\begin{array}{l}\text { Number of } \\
\text { rape survivors }\end{array}$ & $80 \%$ & & $\begin{array}{l}\text { National } \\
\text { Information } \\
\text { Management } \\
\text { System for } \\
\text { GBV }\end{array}$ & $\mathrm{N} / \mathrm{A}$ & $\mathrm{N} / \mathrm{A}$ & $\mathrm{N} / \mathrm{A}$ & Include \\
\hline 7.2 & $\begin{array}{l}\text { Percentage of } \\
\text { health } \\
\text { facilities with } \\
\text { clinical } \\
\text { management } \\
\text { of rape } \\
\text { services }\end{array}$ & $0 \%$ & N/A & $\begin{array}{l}\text { National } \\
\text { Information } \\
\text { Management } \\
\text { System for } \\
\text { GBV }\end{array}$ & & $\mathrm{N} / \mathrm{A}$ & $\begin{array}{l}\text { Service } \\
\text { mapping } \\
\text { exercise at the } \\
\text { health and/or } \\
\text { humanitarian } \\
\text { sector level to } \\
\text { identify service } \\
\text { provision of } \\
\text { clinical } \\
\text { management } \\
\text { of rape }\end{array}$ & Exclude \\
\hline
\end{tabular}




\begin{tabular}{|c|c|c|c|c|c|c|c|c|}
\hline No. & Indicator name & $\begin{array}{l}\text { Overall \% } \\
\text { of } \\
\text { Agencies } \\
\text { Reporting }\end{array}$ & $\begin{array}{l}\text { Place of } \\
\text { Collection }\end{array}$ & $\begin{array}{l}\text { Facilitators } \\
\text { to Routine } \\
\text { Collection }\end{array}$ & $\begin{array}{l}\text { Barriers to } \\
\text { Routine } \\
\text { Collection }\end{array}$ & $\begin{array}{l}\text { Necessary } \\
\text { Modifications }\end{array}$ & $\begin{array}{l}\text { Resources } \\
\text { Needed for } \\
\text { Routine } \\
\text { Collection }\end{array}$ & Exclude/Include \\
\hline 7.3 & $\begin{array}{l}\text { Percentage of } \\
\text { rape survivors } \\
\text { receiving HIV } \\
\text { post-exposure } \\
\text { prophylaxis }\end{array}$ & $70 \%$ & & $\begin{array}{l}\text { National } \\
\text { Information } \\
\text { Management } \\
\text { System for } \\
\text { GBV }\end{array}$ & N/A & $\mathrm{N} / \mathrm{A}$ & $\mathrm{N} / \mathrm{A}$ & Include \\
\hline 7.4 & $\begin{array}{l}\text { Percentage of } \\
\text { rape survivors } \\
\text { receiving } \\
\text { emergency } \\
\text { contraception }\end{array}$ & $30 \%$ & & $\begin{array}{l}\text { National } \\
\text { Information } \\
\text { Management } \\
\text { System for } \\
\text { GBV }\end{array}$ & $\begin{array}{l}\text { No } \\
\text { availability } \\
\text { of } \\
\text { commodity: } \\
\text { No dedicated } \\
\text { emergency } \\
\text { contraceptive } \\
\text { (EC) pill } \\
\text { registered in } \\
\text { Jordan } \\
\text { Insufficient } \\
\text { security and } \\
\text { privacy } \\
\text { measures set } \\
\text { in place }\end{array}$ & $\mathrm{N} / \mathrm{A}$ & $\begin{array}{l}\text { Training on the } \\
\text { new IAFM } \\
\text { guidelines } \\
\text { Training } \\
\text { providers on } \\
\text { the different } \\
\text { contraceptive } \\
\text { modalities that } \\
\text { can be used for } \\
\text { EC } \\
\text { Resources and } \\
\text { training } \\
\text { regarding } \\
\text { security \& data } \\
\text { privacy }\end{array}$ & Include \\
\hline 7.5 & $\begin{array}{l}\text { Number of } \\
\text { rape survivors } \\
\text { requesting } \\
\text { abortion }\end{array}$ & $0 \%$ & $\mathrm{~N} / \mathrm{A}$ & $\begin{array}{l}\text { National } \\
\text { Information } \\
\text { Management } \\
\text { System for } \\
\text { GBV }\end{array}$ & $\begin{array}{l}\text { Legal status } \\
\text { of abortion in } \\
\text { Jordan } \\
\text { Potential risk } \\
\text { for client and } \\
\text { primary care } \\
\text { provider } \\
\text { Insufficient } \\
\text { security and } \\
\text { privacy } \\
\text { measures set } \\
\text { in place } \\
\text { Service not } \\
\text { routinely } \\
\text { provided }\end{array}$ & $\mathrm{N} / \mathrm{A}$ & $\mathrm{N} / \mathrm{A}$ & Exclude \\
\hline 7.6 & $\begin{array}{l}\text { Number of } \\
\text { rape survivors } \\
\text { receiving } \\
\text { induced } \\
\text { abortion care } \\
\text { or referral }\end{array}$ & $0 \%$ & $\mathrm{~N} / \mathrm{A}$ & $\begin{array}{l}\text { National } \\
\text { Information } \\
\text { Management } \\
\text { System for } \\
\text { GBV }\end{array}$ & $\begin{array}{l}\text { Legal status } \\
\text { of abortion in } \\
\text { Jordan } \\
\text { Policy and } \\
\text { legislative } \\
\text { changes } \\
\text { Insufficient } \\
\text { security and } \\
\text { privacy } \\
\text { measures set } \\
\text { in place }\end{array}$ & $\mathrm{N} / \mathrm{A}$ & $\begin{array}{l}\text { Training on the } \\
\text { new IAFM } \\
\text { guidelines } \\
\text { Integration into } \\
\text { HIS/existing } \\
\text { data collection } \\
\text { system } \\
\text { VCAT sessions } \\
\text { Service } \\
\text { mapping } \\
\text { exercise at the } \\
\text { health and/or } \\
\text { humanitarian } \\
\text { sector level to } \\
\text { identify service } \\
\text { provision of } \\
\text { abortions } \\
\text { Resources and } \\
\text { training } \\
\text { regarding } \\
\text { security \& data } \\
\text { privacy }\end{array}$ & Include \\
\hline 7.7 & $\begin{array}{l}\text { Availability of } \\
\text { intimate } \\
\text { partner } \\
\text { violence front } \\
\text { line support } \\
\text { (LIVES) }\end{array}$ & $0 \%$ & $\mathrm{~N} / \mathrm{A}$ & $\begin{array}{l}\text { National } \\
\text { Information } \\
\text { Management } \\
\text { System for } \\
\text { GBV }\end{array}$ & $\begin{array}{l}\text { Service not } \\
\text { routinely } \\
\text { provided }\end{array}$ & $\mathrm{N} / \mathrm{A}$ & $\mathrm{N} / \mathrm{A}$ & Exclude \\
\hline
\end{tabular}




\begin{tabular}{|c|c|c|c|c|c|c|c|c|}
\hline No. & Indicator name & $\begin{array}{l}\text { Overall \% } \\
\text { of } \\
\text { Agencies } \\
\text { Reporting }\end{array}$ & $\begin{array}{l}\text { Place of } \\
\text { Collection }\end{array}$ & $\begin{array}{l}\text { Facilitators } \\
\text { to Routine } \\
\text { Collection }\end{array}$ & $\begin{array}{l}\text { Barriers to } \\
\text { Routine } \\
\text { Collection }\end{array}$ & $\begin{array}{l}\text { Necessary } \\
\text { Modifications }\end{array}$ & $\begin{array}{l}\text { Resources } \\
\text { Needed for } \\
\text { Routine } \\
\text { Collection }\end{array}$ & Exclude/Include \\
\hline \multicolumn{9}{|l|}{ HIV } \\
\hline 8.1 & $\begin{array}{l}\text { Antiretroviral } \\
\text { therapy } \\
\text { coverage } \\
\text { among people } \\
\text { living with HIV, } \\
\text { disaggregated }\end{array}$ & $0 \%$ & N/A & $\begin{array}{l}\text { National } \\
\text { Reporting } \\
\text { System } \\
\text { controlled by } \\
\text { the MoH }\end{array}$ & $\begin{array}{l}\text { National HIV } \\
\text { reporting } \\
\text { requirements } \\
\text { and } \\
\text { management } \\
\text { protocols for } \\
\text { individual } \\
\text { cases }\end{array}$ & N/A & N/A & Exclude \\
\hline 8.2 & $\begin{array}{l}\text { Percentage of } \\
\text { exposed } \\
\text { individuals } \\
\text { receiving post- } \\
\text { exposure } \\
\text { prophylaxis }\end{array}$ & $0 \%$ & $\mathrm{~N} / \mathrm{A}$ & $\begin{array}{l}\text { National } \\
\text { Reporting } \\
\text { System } \\
\text { controlled by } \\
\text { the MoH }\end{array}$ & $\begin{array}{l}\text { National HIV } \\
\text { reporting } \\
\text { requirements } \\
\text { and } \\
\text { management } \\
\text { protocols for } \\
\text { individual } \\
\text { cases }\end{array}$ & N/A & $\mathrm{N} / \mathrm{A}$ & Exclude \\
\hline 8.3 & $\begin{array}{l}\text { Percentage of } \\
\text { donated blood } \\
\text { units screened } \\
\text { for HIV in } \\
\text { quality } \\
\text { assured } \\
\text { manner }\end{array}$ & $0 \%$ & $\mathrm{~N} / \mathrm{A}$ & $\begin{array}{l}\text { National } \\
\text { Reporting } \\
\text { System } \\
\text { controlled by } \\
\text { the MoH }\end{array}$ & $\begin{array}{l}\text { National HIV } \\
\text { reporting } \\
\text { requirements } \\
\text { and } \\
\text { management } \\
\text { protocols for } \\
\text { individual } \\
\text { cases } \\
\text { Not relevant } \\
\text { outside } \\
\text { hospital } \\
\text { settings }\end{array}$ & N/A & $\mathrm{N} / \mathrm{A}$ & Exclude \\
\hline \multicolumn{9}{|c|}{ Prevention of mother-to-child transmission } \\
\hline 9.1 & $\begin{array}{l}\text { Percentage of } \\
\text { antenatal care } \\
\text { clients } \\
\text { receiving } \\
\text { syphilis } \\
\text { screening and } \\
\text { treatment }\end{array}$ & $0 \%$ & $\mathrm{~N} / \mathrm{A}$ & $\mathrm{N} / \mathrm{A}$ & $\begin{array}{l}\text { National HIV } \\
\text { reporting } \\
\text { requirements } \\
\text { and } \\
\text { management } \\
\text { protocols for } \\
\text { individual } \\
\text { cases }\end{array}$ & N/A & $\mathrm{N} / \mathrm{A}$ & Exclude \\
\hline 9.2 & $\begin{array}{l}\text { Percentage of } \\
\text { antenatal care } \\
\text { clients offered } \\
\text { testing for HIV }\end{array}$ & $0 \%$ & N/A & N/A & $\begin{array}{l}\text { National HIV } \\
\text { reporting } \\
\text { requirements } \\
\text { and } \\
\text { management } \\
\text { protocols for } \\
\text { individual } \\
\text { cases }\end{array}$ & N/A & N/A & Exclude \\
\hline 9.3 & $\begin{array}{l}\text { Percentage of } \\
\text { HIV-positive } \\
\text { pregnant } \\
\text { people } \\
\text { receiving } \\
\text { antiretroviral } \\
\text { therapy }\end{array}$ & $0 \%$ & N/A & N/A & $\begin{array}{l}\text { National HIV } \\
\text { reporting } \\
\text { requirements } \\
\text { and } \\
\text { management } \\
\text { protocols for } \\
\text { individual } \\
\text { cases }\end{array}$ & N/A & N/A & Exclude \\
\hline 9.4 & $\begin{array}{l}\text { Percentage of } \\
\text { all deliveries to } \\
\text { HIV-positive } \\
\text { mothers } \\
\text { receiving } \\
\text { antiretrovirals }\end{array}$ & $0 \%$ & N/A & N/A & $\begin{array}{l}\text { National HIV } \\
\text { reporting } \\
\text { requirements } \\
\text { and } \\
\text { management } \\
\text { protocols for } \\
\text { individual } \\
\text { cases }\end{array}$ & N/A & N/A & Exclude \\
\hline
\end{tabular}




\begin{tabular}{|c|c|c|c|c|c|c|c|c|}
\hline No. & Indicator name & $\begin{array}{l}\text { Overall \% } \\
\text { of } \\
\text { Agencies } \\
\text { Reporting }\end{array}$ & $\begin{array}{l}\text { Place of } \\
\text { Collection }\end{array}$ & $\begin{array}{l}\text { Facilitators } \\
\text { to Routine } \\
\text { Collection }\end{array}$ & $\begin{array}{l}\text { Barriers to } \\
\text { Routine } \\
\text { Collection }\end{array}$ & $\begin{array}{l}\text { Necessary } \\
\text { Modifications }\end{array}$ & $\begin{array}{l}\text { Resources } \\
\text { Needed for } \\
\text { Routine } \\
\text { Collection }\end{array}$ & Exclude/Include \\
\hline 10.1 & $\begin{array}{l}\text { Percentage of } \\
\text { STI/RTI cases } \\
\text { managed }\end{array}$ & $70 \%$ & & $\begin{array}{l}\text { National } \\
\text { Reporting } \\
\text { System: } \\
\text { centralized } \\
\text { system in the } \\
\text { MoH, NSSRH } \\
\text { (Higher } \\
\text { Population } \\
\text { Council) }\end{array}$ & $\begin{array}{l}\text { Insufficient } \\
\text { security and } \\
\text { privacy } \\
\text { measures set } \\
\text { in place }\end{array}$ & $\begin{array}{l}\text { Include } \\
\text { indicator on } \\
\text { referrals to } \\
\mathrm{MoH}\end{array}$ & $\begin{array}{l}\text { Develop } \\
\text { materials and } \\
\text { training on a } \\
\text { wide range of } \\
\text { STIs } \\
\text { Training for } \\
\text { healthcare } \\
\text { providers } \\
\text { Resources and } \\
\text { training } \\
\text { regarding } \\
\text { security \& data } \\
\text { privacy }\end{array}$ & Include \\
\hline
\end{tabular}


Table 3

List of indicators that should be excluded according to our stakeholders, with primary rationale

\begin{tabular}{|c|c|c|}
\hline & Indicator number and name & Rationale for exclusion \\
\hline \multirow[t]{2}{*}{ Contraception } & \multirow{2}{*}{$\begin{array}{l}\text { 1.4: Percentage of clients adopting modern } \\
\text { contraception method after abortion }\end{array}$} & - Service not provided \\
\hline & & - Insufficient security and privacy measures set in place \\
\hline \multirow{2}{*}{$\begin{array}{l}\text { Comprehensive } \\
\text { abortion care }\end{array}$} & \multirow[t]{2}{*}{ 2.1: Number of clients requesting an abortion } & - Potential risk for the client and primary care provider \\
\hline & & - Insufficient security and privacy measures set in place• \\
\hline \multirow[t]{10}{*}{ Maternal Health } & 3.9: Availability of PAC & $\begin{array}{l}\text { - Service mapping exercise }{ }^{6} \text { at the health and/or humanitarian } \\
\text { sector level }\end{array}$ \\
\hline & $\begin{array}{l}\text { 3.10: Availability of basic emergency obstetric care } \\
\text { (BEmOC) }\end{array}$ & $\begin{array}{l}\text { - Service mapping exercise at the health and/or humanitarian } \\
\text { sector level }\end{array}$ \\
\hline & $\begin{array}{l}\text { 3.11: Availability of comprehensive emergency } \\
\text { obstetric care (CEmOC) }\end{array}$ & $\begin{array}{l}\text { - Service mapping exercise at the health and/or humanitarian } \\
\text { sector level }\end{array}$ \\
\hline & \multirow{3}{*}{ 3.12: Availability of skilled personal } & - High quality medical care \\
\hline & & -In-patient health care system \\
\hline & & - Service mapping exercise \\
\hline & 3.13: Number of ANC clients with tetanus vaccination & - Low burden of disease, service not routinely provided \\
\hline & $\begin{array}{l}\text { 3.14: Number of ANC clients receiving preventive } \\
\text { therapy for malaria }\end{array}$ & - Low burden of disease, service not routinely provided \\
\hline & $\begin{array}{l}\text { 3.15: Number of ANC clients receiving syphilis } \\
\text { screening }\end{array}$ & - Low burden of disease, service not routinely provided \\
\hline & $\begin{array}{l}\text { 3.16: Number of ANC clients receiving urinary tract } \\
\text { infection screening or treatment }\end{array}$ & - Low burden of disease, information not actionable \\
\hline \multirow[t]{5}{*}{ Newborn Health } & 4.6: Availability of KMC & - Service not routinely provided; information not actionable \\
\hline & \multirow[t]{3}{*}{ 4.7: Availability of neonatal resuscitation } & - High quality medical care \\
\hline & & •In-patient health care system \\
\hline & & - Service mapping exercise \\
\hline & $\begin{array}{l}\text { 4.11: Number of newborns initiating breastfeeding } \\
\text { early }\end{array}$ & - Information not actionable \\
\hline \multirow[t]{8}{*}{ Child health } & 5.2: Under 5 mortality rate & - Population-level indicator with impractical denominator \\
\hline & $\begin{array}{l}\text { 5.3: Percentage of children under } 5 \text { with suspected } \\
\text { pneumonia taken to appropriate health facility }\end{array}$ & - Population-level indicator with impractical denominator \\
\hline & \multirow[t]{2}{*}{ 5.5: Percentage of children under 5 who are wasted } & - Low burden of disease, \\
\hline & & - Population-level indicator with impractical denominator \\
\hline & $\begin{array}{l}\text { 5.7: Number of children presenting with fever tested for } \\
\text { malaria in endemic settings }\end{array}$ & $\begin{array}{l}\text { - Low burden of disease, specific infectious disease reporting } \\
\text { requirements and management protocols for individual cases }\end{array}$ \\
\hline & $\begin{array}{l}\text { 5.8: Number of confirmed cases of malaria in endemic } \\
\text { settings }\end{array}$ & $\begin{array}{l}\text { - Low burden of disease, specific infectious disease reporting } \\
\text { requirements and management protocols for individual cases }\end{array}$ \\
\hline & 5.9: Percentage of confirmed malaria cases treated & $\begin{array}{l}\text { - Low burden of disease, specific infectious disease reporting } \\
\text { requirements and management protocols for individual cases }\end{array}$ \\
\hline & 5.10: Coverage of DPT3 & - Population-level indicator with impractical denominator \\
\hline \multirow{3}{*}{$\begin{array}{l}\text { Adolescent } \\
\text { health }\end{array}$} & 6.1: Adolescent birth rate & - Population-level indicator with impractical denominator \\
\hline & 6.2: Sexual violence against children & $\begin{array}{l}\text { - Information not actionable, population-level indicator with } \\
\text { impractical denominator }\end{array}$ \\
\hline & 6.3: Adolescent mortality rate & - Population-level indicator with impractical denominator \\
\hline
\end{tabular}




\begin{tabular}{|c|c|c|}
\hline & Indicator number and name & Rationale for exclusion \\
\hline & \multirow[t]{2}{*}{$\begin{array}{l}\text { 6.4: Percentage of adolescents living with HIV who are } \\
\text { currently receiving antiretroviral therapy, disaggregated }\end{array}$} & $\begin{array}{l}\text { - National HIV reporting requirements and management } \\
\text { protocols for individual cases, }\end{array}$ \\
\hline & & - Population-level indicator with impractical denominator \\
\hline & 6.5: Immunization coverage rate & - Population-level indicator with impractical denominator \\
\hline & \multirow[t]{2}{*}{ 6.6: Suicide rate, disaggregated } & - Information not actionable, \\
\hline & & - Population-level indicator with impractical denominator \\
\hline \multirow{5}{*}{$\begin{array}{l}\text { Sexual and } \\
\text { gender-based } \\
\text { violence }\end{array}$} & $\begin{array}{l}\text { 7.2: Percentage of health facilities with clinical } \\
\text { management of rape services }\end{array}$ & $\begin{array}{l}\text { - Service mapping exercise at the health and/or humanitariar } \\
\text { sector level }\end{array}$ \\
\hline & \multirow[t]{3}{*}{ 7.5: Number of rape survivors requesting an abortion } & - Potential risk for the client \\
\hline & & - Insufficient security and privacy measures set in place \\
\hline & & - Service not provided \\
\hline & $\begin{array}{l}\text { 7.7: Availability of intimate partner violence front line } \\
\text { support (LIVES) }\end{array}$ & - Service not routinely provided \\
\hline \multirow[t]{2}{*}{ HIV } & $\begin{array}{l}\text { 8.1: Antiretroviral therapy coverage among people } \\
\text { living with HIV, disaggregated }\end{array}$ & $\begin{array}{l}\text { - National HIV reporting requirements and management } \\
\text { protocols for individual cases }\end{array}$ \\
\hline & $\begin{array}{l}\text { 8.2: Percentage of exposed individuals receiving post- } \\
\text { exposure prophylaxis }\end{array}$ & $\begin{array}{l}\text { - National HIV reporting requirements and management } \\
\text { protocols for individual cases }\end{array}$ \\
\hline
\end{tabular}

${ }^{6}$ Given that Jordan does not have a nationally endorsed HIS, the indicators that ask for number of facilities, would either need to be reworded or conducted as a service mapping exercise at the health and humanitarian sector level.

Service mapping exercise_aims to examine what services and programs, and by whom are offered; the services and programs that other agencies within the same communities are offering. It seems to also examine the links between services and programs provided and utilized by the target population. Service mapping also aims to identify any service and/or programming gaps that may exist in the community that might need to be addressed (48). 
Table 4

Existing monitoring and evaluations systems reported by our stakeholders, by domain of indicators

\begin{tabular}{|c|c|}
\hline SRNMCAH domain & Existing System \\
\hline \multirow[t]{6}{*}{ Contraception } & - WizMonitor ${ }^{7}$ \\
\hline & - Continuity of care workers ${ }^{8}$ \\
\hline & - Internal HIS 9 \\
\hline & • Hakeem/manual \\
\hline & • WizMonitor \\
\hline & • Internal HIS \\
\hline \multirow[t]{4}{*}{ Comprehensive abortion care } & - Continuity of care worker \\
\hline & • Internal HIS \\
\hline & - Patient charts \\
\hline & - Miscarriage spreadsheet \\
\hline Maternal health & - Resource and systems are centralized through the $\mathrm{MOH}$ \\
\hline \multirow[t]{6}{*}{ Newborn health } & - WizMonitor \\
\hline & - Continuity of care workers \\
\hline & • Internal HIS \\
\hline & -WizMonitor \\
\hline & • Tally sheets/Internal HIS \\
\hline & • Internal HIS \\
\hline \multirow[t]{6}{*}{ Child health } & • WizMonitor \\
\hline & - Continuity of care workers \\
\hline & • Internal HIS \\
\hline & • WizMonitor \\
\hline & - Tally sheets/Internal HIS \\
\hline & •Internal HIS \\
\hline \multirow[t]{6}{*}{ Adolescent health } & • WizMonitor \\
\hline & - Continuity of care workers \\
\hline & •Internal HIS \\
\hline & • WizMonitor \\
\hline & • Tally sheets/Internal HIS \\
\hline & • Internal HIS \\
\hline \multirow[t]{7}{*}{ Sexual and gender-based violence (SGBV) } & • WizMonitor \\
\hline & • K.N.A.C.K \\
\hline & - Continuity of care workers \\
\hline & • Internal HIS \\
\hline & • WizMonitor \\
\hline & - Tally sheets \\
\hline & • Internal HIS \\
\hline HIV & - System controlled by the $\mathrm{MOH}$ \\
\hline РМТСТ & $\cdot N / A$ \\
\hline
\end{tabular}




\begin{tabular}{|l|l|}
\hline SRNMCAH domain & Existing System \\
\hline Sexually transmitted infections (STIS) and reproductive tract infections (RTIs) & $\bullet$ WizMonitor \\
& $\cdot$ Continuity of care workers \\
& $\bullet$ Internal HIS \\
& $\cdot$ WizMonitor \\
& $\bullet$ Tally sheets/Internal HIS \\
\hline
\end{tabular}

${ }^{7}$ WizMonitor: Name of the data-collection software used by UNFPA

${ }^{8}$ Continuity of care workers: Staff that have been hired to collect and insert patient data on a daily basis. At the time of the assessment data was being inserted and stored in an excel sheet, however, IMC was in the process of developing an internal HIS system from the bottom-up.

${ }^{9}$ Internal HIS: International Rescue Commission, UNRWA and UNHCR have implemented and utilize an internal HIS system for all their data collection and reporting efforts.

\section{Figures}

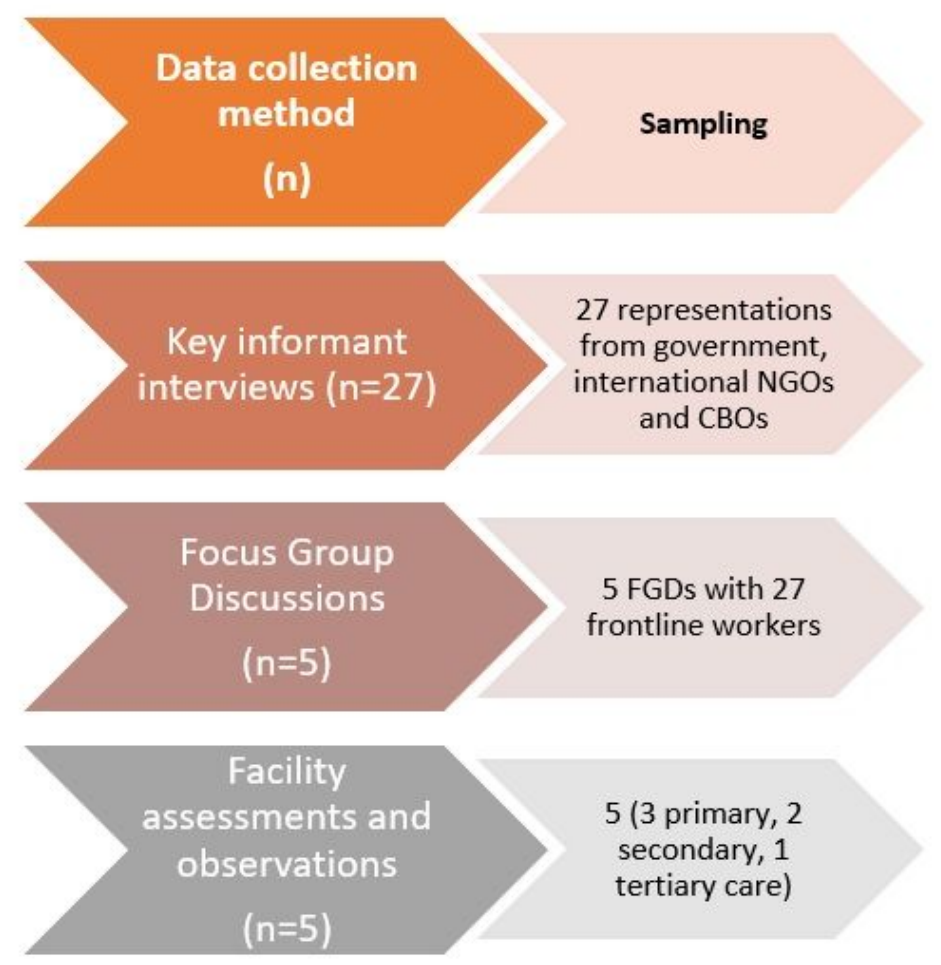

\section{Figure 1}

\section{Data collection for Phase II}

Acronyms: Non-governmental organization (NGO); Community based organization (CBO) 
- Early marriage

- Maternal deaths among those aged 15 and younger

- Youth-friendly services

- GBV case management

- Supply chains

- Stock outs

- Coordination

\section{Figure 2}

Topics that should be included in the core list of SRMNCAH indicators

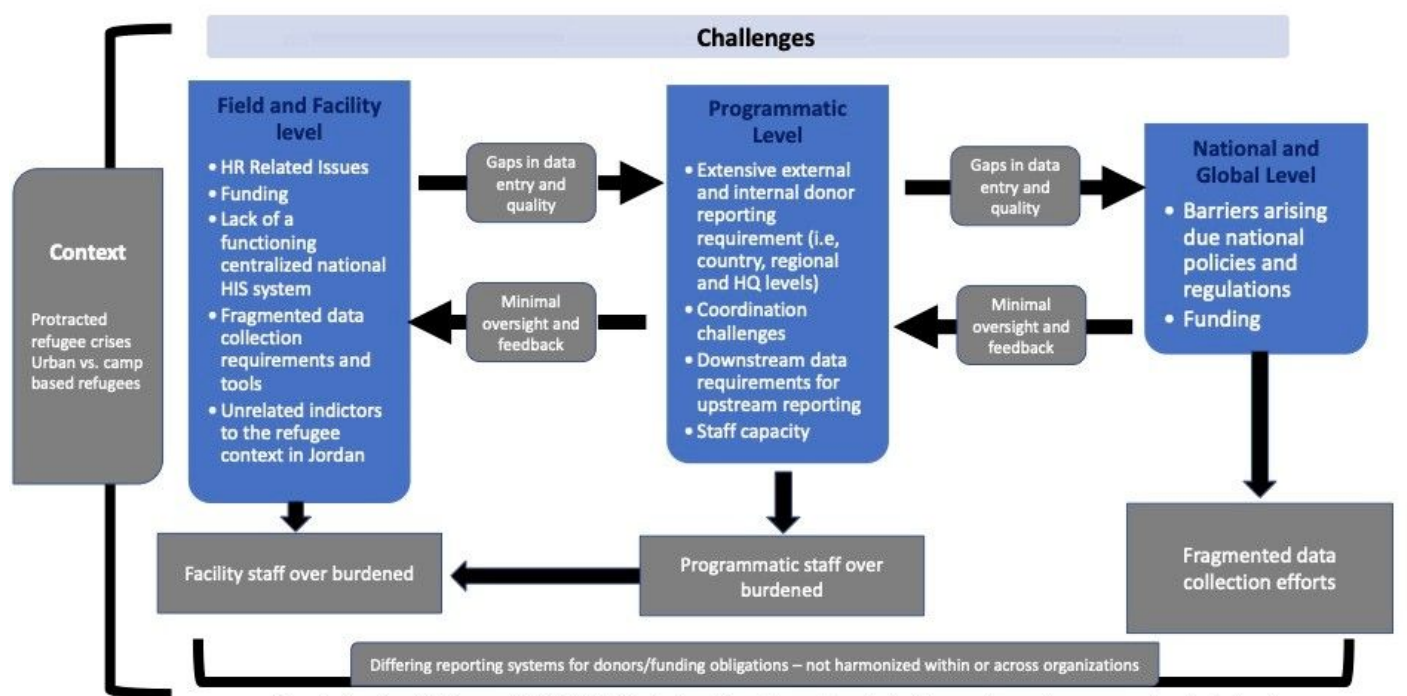

Gaps in timely, reliable, quality SRMNCAH indicators for evidence-based decision making and program planning in Jordan

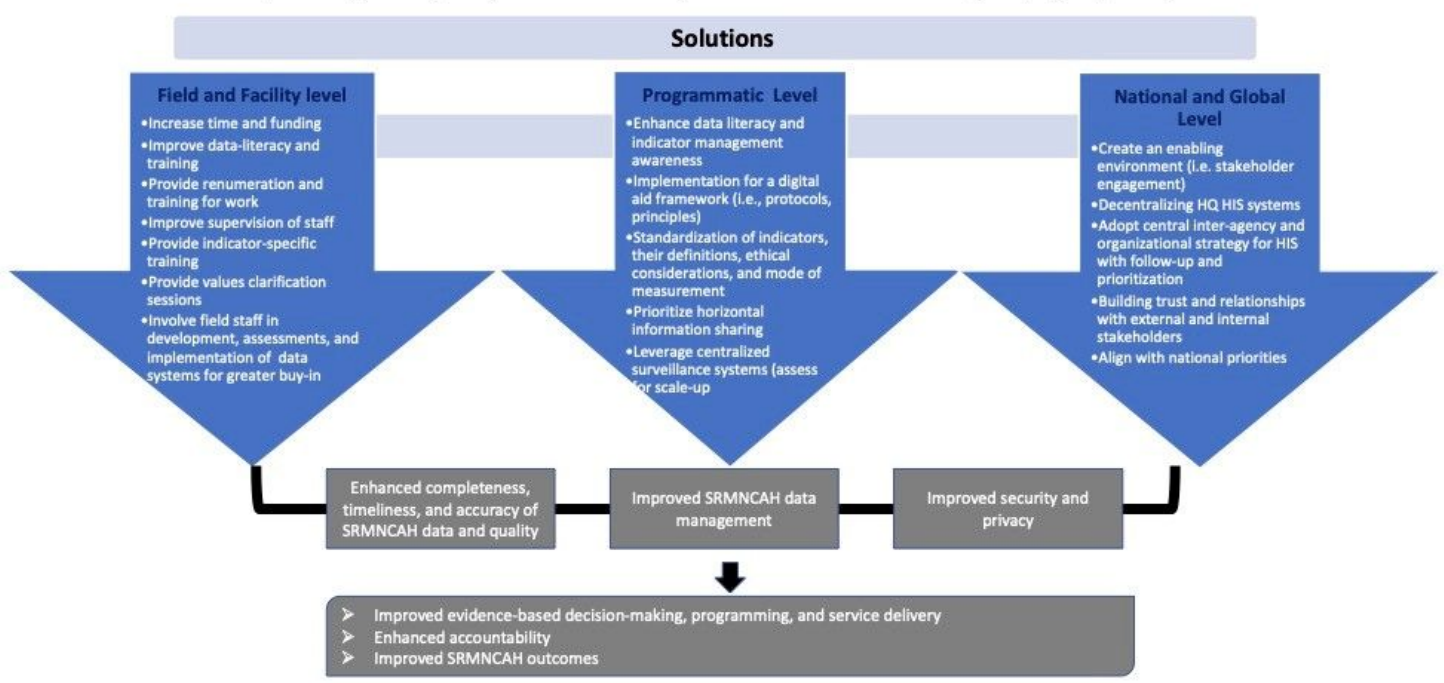

Figure 3

Challenges and solutions for timely, reliable, quality SRMNCAH indicator reporting at the facility, programmatic, and national and global levels in Jordan, reported by the study participants 